Source: K. Caminada, K. Goudswaard, C. Wang \& J. Wang, Income inequality and fiscal redistribution in 31 countries after the crisis, Comparative Economic Studies (published online: 16 November 2018)

\title{
Income inequality and fiscal redistribution in 31 countries after the crisis ${ }^{*}$
}

\author{
Koen Caminada, Leiden University \& Netspar, E-mail: c.l.j.caminada@law.leidenuniv.nl \\ Kees Goudswaard, Leiden University \& Netspar, E-mail: k.p.goudswaard@law.leidenuniv.nl \\ Chen Wang, Shanghai University of Finance and Economics \& Leiden University, E-mail \\ wang.chen@mail.shufe.edu.cn
}

Jinxian Wang, Central South University \& Leiden University, E-mail: wangjinxian@csu.edu.cn

\begin{abstract}
In this paper we analyze fiscal redistribution after the Great Recession. Are welfare states still effective in reducing income inequality? We use recent micro-data from the Luxembourg Income Study (LIS) to examine redistribution from transfers and income taxes, and the several underlying social programs that drive the changes in 31 countries. We employ a budget incidence simulation model to investigate to what extent several social transfers and income taxes reduce income inequality. This paper is a cross country comparison at one moment in time for as many countries as possible and for the most recent data year available. The study is novel because it offers an extensive decomposition of the redistributive effects of social transfer programs. In addition, we present sensitivity analyses, applying various measures of global inequality and different equivalence scale methods. Finally, this study offers a detailed analysis of fiscal redistribution for both the working-age population and the total population. On average we find that social transfers and income taxes reduce the Gini by 31 percent. In most countries pensions are a dominant factor. After performing a number of sensitivity analyses, we conclude that the redistributive impact of the welfare state is still substantial.
\end{abstract}

Key words: welfare states, social income transfers, inequality, Gini coefficient JEL-codes: H53, H55, and I32

\footnotetext{
This study is part of the research program Reform of Social Legislation of Leiden University. Financial support of Instituut GAK, China National Foundation of Natural Sciences (Project 71703088) and Shanghai Pujiang Program (Project 17PJC045) are gratefully acknowledged. We thank the LIS Cross-National Data Center in Luxembourg for permission to post the Budget Incidence Fiscal Redistribution Dataset on Income Inequality at our website (Leiden University / LLS / Economics / Data).
} 


\section{Introduction}

The overall tendency over the past two or three decades has been for an increase in income inequality in the large majority of rich nations. In OECD countries, the widening of the income gap between rich and poor has been mainly driven by greater inequality in market income from the mid-1980s (OECD, 2008, 2011 and 2015). Several explanations of income inequality have been introduced by researchers in sociology, economics, and political science. ${ }^{1}$ One of the main driving forces behind disposable income distribution is the reduction of inequality through the tax-transfer system. ${ }^{2}$ The overall redistributive effect can be divided into redistribution by transfers and by taxes, or even into more details. ${ }^{3}$ In the mid-2000s, the average redistributive effect achieved by public cash transfers is twice as large as that achieved through household taxes, although for example the United States stands out for achieving a greater part of redistribution by taxes (Wang et al 2012 and 2014; OECD, 2008, 2011 and Whiteford, 2010). As the tax and transfer system was only able to offset a part of the rise in market income inequality over the last 25 years, disposable income (i.e. after taxes and social benefits) has also become more unequal in many countries.

The growing interest in national and cross-national differences in earnings and income inequality has produced a wide range of studies. An important development has been the launching of the Luxembourg Income Study (LIS) in which microdata-sets from various countries have been "harmonized". LIS offers micro-data that are comparable, detailed and accurate. Specifically, LIS offers data on a large number of individual sources of income from both the private and public sectors (LIS, 2017). Consequently it is possible to study income inequality across countries and years (see Atkinson et al., 1995).

In this paper we use the most recent LIS data to analyze fiscal redistribution after the Great Recession. Are welfare states still effective in reducing income inequality? On the one hand, some social transfers, notably unemployment benefits, work as automatic stabilizers and will increase in times of economic downturn. On the other hand, many countries have implemented retrenchments on social programs during the crisis in order to restore public finances.

We focus on the effect of income taxes (including social contributions) and transfers in redistributing income. Our expectation is that social transfers are mainly directed to lower income groups, while income taxes are mainly paid by the rich, and therefore both will have an impact on income (re)distribution. We use the traditional budget incidence approachdespite some methodological problems we will address - to study the combined effects of income taxes and transfers on the income (re)distribution. The distribution of market income is compared with the distribution of income after taxes and after social transfers. The change in summary measures of inequality between pre- and post-government income represents direct government redistribution.

Many factors make it difficult to compare the redistributive effect of taxes and transfers across countries (differences in income concepts, the income units, (summary) measures, equivalence adjustments and other factors). Moreover, there are numerous possible ways to analyze the impact of taxes and transfers on the distribution of income; some of these approaches are listed

1 Among others Kuznets (1955), Nielsen \& Alderson (1997), Gustafsson \& Johansson (1999), Chevan \& Stokes (2000), Atkinson (2015) and Piketty (2014).

2 Among others Danziger et al. (1981), Gottschalk \& Smeeding (1997 and 2000), Atkinson \& Brandolini (2001), Smeeding (2000 and 2004), Atkinson (2003), Brandolini and Smeeding (2007), Belfield et al. (2017) and Caminada \& Goudswaard (2001), Wang et al (2012 and 2014).

3 Among others Plotnick (1984), Ferrarini \& Nelson (2003), Kristjánsson (2011), Fuest et al. (2010), Jesuit \& Mahler (2010, 2017), Causa \& Hermansen (2017) and Caminada \& Goudswaard (2001), Wang et al (2012 and 2014). 
in our references. ${ }^{4}$ It is generally agreed upon that there is no single 'correct' methodology. However, the budget incidence approach is - still - a standard methodology for studying the combined effects of all taxes and transfers on the magnitude of (re)distributing income.

In this paper we elaborate on the work of Jesuit \& Mahler (2010 and 2017), Mahler and Jesuit (2006), and Wang et al (2012 and 2014). We offer a user-friendly Leiden LIS Budget Incidence Fiscal Redistribution Dataset on Income inequality (Wang \& Caminada, 2017). Also, we undertake a detailed study (compared to Wang et al, 2012 and 2014), containing a simulation approach which allows us to decompose income inequality through income taxes and several social transfers. It should be mentioned here that social transfers include public pensions. We employ a budget incidence simulation model to investigate to what extent several social transfers and income taxes reduce income inequality in 31 countries. Other recent studies in the field, Jesuit \& Mahler (2017) and Causa \& Hermansen (2017), analyze the trend of income inequality and fiscal redistribution. This paper is a cross country comparison at one moment in time for as many countries as possible and for the most recent data year available. The study is novel because it offers an extensive decomposition of the redistributive effects of social transfer programs. In addition, we present sensitivity analyses, applying various measures of global inequality and different equivalence scale methods. Finally, this study offers a detailed analysis of fiscal redistribution for both the working-age population and the total population. The paper is organized as follows. In Section 2 we summarize literature on the redistributive effect of taxes and transfers in LIS countries. Section 3 presents our research method. Section 4 provides a descriptive analysis of income inequality and redistribution across 31 countries around 2013. Section 5 presents the empirical results of our detailed decomposition of the redistributive effect of social transfers and income taxes across countries. Section 6 contains sensitivity analyses. Section 7 concludes the paper.

\section{Income inequality and the redistributive effects of taxes and transfers across countries}

The relationship between income inequality and redistribution in a cross-country perspective is not crystal clear (see on this Lambert et al., 2010). A large number of articles discuss the relationship between income inequality and redistribution among countries. Despite recent empirical evidence suggesting that there is more redistribution when pre-tax income inequality is high, it is claimed by others that societies with low pre-tax income inequality redistribute more than less equal societies. The main reason for the confusion stems from differences in measurement strategies. Indeed, with three distributions involved (pre-taxtransfer income, post-tax-transfer income, and the tax/benefit-system), and with different inequality measures to sum up these distributions, not surprisingly the literature offers a plethora of research methods and empirical results. Below we shall briefly review the main ones, restricting us to Gini-based literature and applications, which are by far the most prevalent.

Several studies analyze income distribution across countries, indicating that the role of social programs (taxes and transfers) is important in the magnitude of income redistribution. ${ }^{5}$ Korpi \& Palme (1998) use data from LIS to study different types of welfare states. They illustrate that both the level of transfers and the targeting to the poor are important for reducing income inequality. Bradley et al. (2003) divide the welfare states into three categories (Social Democratic, Christian Democratic and Liberal Democratic) to study government redistribution and distributive profiles of taxes and transfers. Their results indicate that

4 Among others, see Atkinson et al. (2001), Gustafsson \& Johansson (1999) and Lambert et al. (2010).

5 Among others, Atkinson (2003), Atkinson \& Brandolini (2001), Brandolini \& Smeeding (2007), Gottschalk \& Smeeding (1997 and 2000) and Smeeding (2000 and 2004). 
welfare generosity does not have a significant effect on pre-tax and pre-transfer income inequality, but increases the redistributive impact. By using LIS data for the mid-2000s, Pressman (2009) finds a larger proportion of middle-class households in countries with rather progressive national tax systems and relatively generous government spending programs. With respect to the relationship between inequality and redistribution, the results are not always in line with each other. Kenworthy \& Pontusson (2005) examine the trend in market income inequality and redistribution in OECD countries in the 1980s and 1990s, indicating that redistribution increased in most countries. Welfare state policies compensate for the rise in market income inequality across countries.

A recent study by the OECD (Causa \& Hermansen, 2017) concludes that redistribution through income taxes and cash transfers cushions income inequality on average by about 27 percent in OECD countries. This effect would be larger when non cash transfers such as education and health care would be taken into account. Two thirds of the redistributive impact can be attributed to cash transfers and one third to income taxes. The OECD (2016) also finds that redistribution has weakened or stagnated since 2010 in most OECD countries, although there are exceptions. In countries that were hit hard by the crisis, like Greece, Spain and Portugal, redistribution has increased, despite fiscal consolidation measures, because most social transfers, e.g., unemployment benefits work as automatic stabilizers, and their purpose is to increase in the times of economic downturn. Jesuit \& Mahler (2017) compare the redistributive effects of old-age pensions and transfers to those of working-age in 20 developed countries between the late 1960s and 2010. They find that there is substantial variation across countries in overall fiscal redistribution. Transfers account for the majority of the redistribution.

Most studies focus on overall redistribution; others have examined in more detail the impact of income components on overall inequality (Jenkins, 1995; Lerman \& Yitzhaki, 1985; Shorrocks, 1982; Fuest et al., 2010; Kristjánsson, 2011). Ferrarini \& Nelson (2003) focus on the effects of taxation and social insurance in 10 countries around 1995, analyzing inter- and intra- country comparisons of income (re)distribution. Mahler \& Jesuit (2006) divide government redistribution into several components: the redistributive effects from unemployment benefits, from pensions, and from taxes. They apply their empirical exercise for 13 countries with LIS-data around the years 1999/2000. Wang et al (2012 and 2014) update and extend the analyses of Mahler \& Jesuit (2006) by taking into account many more benefits and taxes, and apply a budget incidence analysis to a wider range of 36 countries with LIS data up-to around 2004. They conclude that transfers account for 75 percent of redistribution, while direct taxes account for 25 percent. More than half of total redistribution owing to transfers is caused by pensions, although the redistributive character of pensions varies across countries. Unemployment benefits are the second important program in terms of redistribution, but their redistributive impact is only one fifth of the effect of pensions. Another finding of Mahler and Jesuit (2006) is that redistribution is more strongly related to the size of social benefits than to the extent to which benefits are targeted to lower income groups (targeting efficiency).

Studies that apply tax-benefit instruments sequentially suggest that the redistributive effect of transfers is much more important than taxes (e.g. Jesuit \& Mahler, 2017; Mahler \& Jesuit, 2006; Wang et al, 2012 and 2014). Few other studies comparing the redistributive effects of benefits and taxes simultaneously point in the same direction (e.g. Avram et al., 2014; Immervoll and Richardson, 2011; Joumard et al., 2012; Kenworthy, 2011).

A number of studies are using the EUROMOD microsimulation model to analyze the distributional impact of transfers and taxes. De Agostini et al. (2014) analyze the tax-benefit 
policy reforms that have been implemented after the Great Recession. They find that the changes in direct taxes, pensions and cash benefits had broadly inequality-reducing effects, except in Germany. However, after including the VAT, the policy package appears to have been more regressive. Hills et al. (2014) point out that most of the structural policy changes, especially those introduced in the 2007-2011 crisis onset period, have inequality-increasing effects. Avram et al. (2014) analyze different types of policies in reducing income disparities. They conclude that pensions and direct taxes have the strongest impact on redistribution, despite low progressivity of these programs in some countries. Thus, the size of the programs matters more, than their targeting to lower income groups. As suggested by Figari \& Paulus (2015), the overall redistributive effect of the tax-benefit systems heavily depends on the income concept concerned. They introduce an extended income concept, which also includes indirect taxes, imputed rent and in kind benefits. Applying this concept to three European countries (Belgium, Greece and the United Kingdom), they find that differences in redistribution across countries become smaller.

\section{Research method}

\subsection{Measuring the redistributive effects of income taxes and social transfers}

Usually, the impact of social programs on income inequality is calculated in line with the work of Musgrave et al. (1974), i.e. statutory or budget incidence analysis. A standard analysis of the redistributive effect of taxes and income transfers is to compare pre-tax-transfer income inequality and post-tax-transfer income inequality (OECD 2008: p. 98). Our measure of the redistributive impact of social security on inequality is straightforwardly based on formulas developed by Kakwani (1986) and Ringen (1991):

Redistribution by taxes and social transfers = market income inequality - disposable income inequality

This formula is used to estimate the reduction in inequality produced by taxes and social transfers, where market income inequality is given by a summary statistic of pre-tax, pretransfer incomes and disposable income inequality is given by the same summary statistic of disposable equivalent incomes. Table 1 presents the framework of accounting income inequality and redistribution through various income sources.

Table 1 The income inequality and redistribution accounting framework

Income components

Labor income + capital income + private transfers $=$ Market income

+ Social security transfers

$=$ Gross income

-/- Income taxes and social security contributions

$=$ Disposable income
Income inequality and redistributive effect

Income inequality before social transfers and taxes

-/- Redistributive effect of social transfers

$=$ Income inequality before taxes

-/- Redistributive effect of taxes

$=$ Income inequality after social transfers and taxes 
Of course, also critical literature on budget incidence analyses has emerged - but these criticisms leave the stylized conclusions intact; see a critical survey of efforts to measure budget incidence by Smolensky et al. (1987). The pre-transfer inequality is compared to the post-transfer inequality keeping all other things equal - namely, assuming unchanged household and labor market structures, thus disregarding any possible behavioral changes that the situation of absence of social transfers would involve. Kim (2001) shows that both the generosity and efficiency of the tax/transfer system may influence the level of pre-tax-transfer income inequality. In essence, budget incidence analyses assume that labor supply decisions in a situation with social transfers and social security are equal to a situation without social transfers. So, this standard approach biases the redistributive effect of generous and/or targeted welfare systems. Our estimates for redistribution through income taxes and transfers of each country should consequently be regarded as upper bounds.

In order to assess the partial effects of specific social benefits and taxes on the overall redistribution, we apply a sequential accounting decomposition technique to the Gini. It should be noted, however, that this procedure is somewhat arbitrary since the choice of benchmark income affects the outcome. Applying the redistribution from, say, taxes on gross income rather than market income alters the outcome to some extent. Since taxes are levied on gross income (market income plus social benefits) as a rule in most countries, the redistributive effects may be underestimated. However, there are many differences in the tax treatment, between countries, between types of social benefits and in terms of tax instruments (tax exemptions, preferred taxation, no tax). An extensive inventory and application of these particularities goes behind the scope of this study, but it should be noted that these differences in tax treatment will affect our results to some extent. Nevertheless, the logic of this decomposition of Gini is that taxes are applied to gross income and benefits to market income. This approach has been, among others, advocated by Kakwani (1986).

Our sequential accounting decomposition approach of income inequality follows studies by Mahler \& Jesuit (2006), Kristjánsson (2011) and Kammer et al (2012), with inequality indices accounted sequentially in order to determine the effective distributional impact of different income sources. Other techniques of the decomposition of the Gini coefficient by income source can be found in the literature as well; see e.g. Lerman \& Yitzhaki (1985), Stark et al (1986), Kim (2000), Creedy \& Ven (2001), but the sequential accounting approach is the most straightforward.

Disentangling inequality by income source could be affected by the ordering effect. For example, the partial redistributive effect of a specific social transfer will be highest (smallest) when computed as the first (last) social program. The order of the calculations affects the results. We correct for this as follows: we first consider every specific social transfer as the first program to be added to market income and then the last program following all other transfer programs. Consequently, we get two Ginis. When we take the mean of the decomposition results across countries, the sum of all partial redistributive effects amount (a little) over 100 percent due to missing observations. We rescaled the redistributive effects of each program by applying an adjustment factor to correct for this effect; see Caminada et al (2017a) for details.

\subsection{Data}

The LIS Cross-National Data Center in Luxembourg provides the largest available income database of harmonized microdata collected from 47 countries in Europe, North America, Latin America, Africa, Asia, and Australasia. Harmonized into a common framework, LIS datasets contain household- and person-level data labor income, capital income, social security and private transfers, income taxes and social contributions, demography, 
employment, and expenditures (LIS, 2017). The LIS database allows scholars to access the microdata, so that income inequality measures and fiscal redistribution (and the partial effect per social program) can be derived consistently from the underlying data at the individual and household level. ${ }^{6}$ LIS micro data seems to be the best available data for describing how income inequality and the redistributive effects of taxes and transfers vary across countries (Nolan \& Marx, 2009; Smeeding \& Latner, 2015).

However, country-comparative and trend analyses of income distribution based on LIS gross/net datasets should be done with caution (Gornick et al., 2013; Nieuwenhuis et al., 2016)). LIS provides gross income data in most countries and years while providing income data that are net of (income) taxes in others. Of the 293 LIS datasets available at the time of writing, 194 are classified as gross, 84 as net and 15 as 'mixed'; see Documentation Guide Leiden LIS Budget Incidence Fiscal Redistribution Dataset on Income inequality (Wang \& Caminada, 2017) for a specification. Since we are interested in the resdistributive effects of social transfers and income taxes and social contributions, this analysis only considers 31 LIScountries for which full tax-benefit information is available (classified by LIS as 'gross'). ${ }^{7+8}$

In the empirical literature, the selection of countries and data-years differs due to the consideration of data quality. From nearly 300 variables in the dataset, we choose those related to household income (all kinds of income sources), total number of persons in a household and household weight (in order to correct sample bias or non-sampling errors) to measure income inequality and the redistributive effect across countries. In line with LIS convention and the work of Mahler \& Jesuit (2006) and Wang et al (2012), we have included households which report zero market income (i.e., all of their income is derived from the state) but have excluded households that report zero disposable income.

\subsection{Measurement issues}

The unit of analysis is an important issue in income distribution studies. It is evident that the ultimate source of concern is the welfare of the individual. However, an individual is often not the appropriate unit of analysis. E.g. children and spouses working at home do not have recorded income, but may nevertheless be enjoying a high standard of living as a result of income sharing with parents/spouses. How to solve the problem of the key question of the unit of analysis?

Traditionally, studies have used household income per capita to adjust total incomes according to the number of persons in the household. In the last decades, equivalence scales have been widely used in the literature on income distribution (Figini, 1998). Equivalence scale elasticity

6 The distinctive feature and value-added of LIS is the access it provides to a set of harmonized micro data files supplied by participating statistical agencies at the country level (Ravallion (2015: p. 529): Harmonization of income data increases quality and comparability across nations and across time; see Smeeding \& Latner (2015) for a critical review of three other popular data sets which summarize inequality across countries and years (World Development Indicators ('WDI')/'PovcalNet' and 'All the Ginis'). Following Ravallion (2015: p. 529): There are pros and cons of each source. While World Income Inequality Database (WIID) is the largest (by far) it is probably the least methodologically consistent internally, while LIS is the smallest but most consistent. PovcalNet and the WDI are somewhere between the two.

7 The redistributive effect of taxes can not be calculated from net datasets of LIS, because gross income equals disposable income. Moreover, mixed datasets in LIS are a special case in which total income can be gross of income taxes but net of contributions, or vice versa, causing a bias in the calculation of the redistributive effect of 'taxes'. As a result, we do not take into account the following LIS countries: Belgium, China, Colombia, Egypt, France, Georgia, Hungary, Italy, Mexico, Paraguay, Russia, Serbia, Slovenia and Uruguay. Moreover, we exclude Romania, because the latest data year available refers to 1997.

8 In the LIS classification employers' social contributions are included in the trajectory from market income to disposable income. However, Guillaud et al (2017) show that employers' social contributions are (arbitrarily) excluded in some countries. 
for the LIS database is set around 0.5. This implies that where the income of a household of one person is 100, a household of two persons must have an income of 140 to have equivalent incomes. Alternatively an one-person household must have 70 percent of the total income of a two-person household to have equivalent income. In our comparative analysis we use this equivalence scale of LIS. However, it has been shown that the choice of equivalence scales affects international comparisons of income inequality. Alternative adjustment methods would affect the ranking of countries, although the broad pattern remains the same (Atkinson et al., 1995: 52). As a robustness check, we apply two other equivalence scales methods as well; see section 6.1 .

We have employed standard LIS top- and bottom-coding conventions, top-coding income at 10 times the median of non-equivalized income and bottom-coding income at 1 percent of equivalized mean income. That is, income in the top of the distribution is cut off by ten times the median of the non-equivalized household income. Income at the bottom of the distribution is replaced by one percent of the average equivalized household income. The bottom coding is particularly relevant for households without market income. Without bottom-coding, these households would not be included in the calculation of the Gini coefficient of market income. On the other hand, these households would again be present in the calculation of the Gini coefficient on the basis of secondary income components as these households are entirely dependent on this. In other words, bottom-coding ensures that the calculations of the Gini coefficients are carried out over the same selection of households. Household weights are applied for calculation of Gini coefficients.

Levels of inequality can be shown in several ways, e.g., by Lorenz curves, specific points on the percentile distribution (P10 or P90), decile ratios (P90/P10), and Gini coefficients or many other summary statistics of inequality. All (summary) statistics of inequality can be used to rank income inequality in LIS countries, but they do not always tell the same story. In this paper we mainly use the Gini coefficient, although a sensitivity analyses illustrates to what extent the empirical results for fiscal redistribution are affected by the choice of the global income inequality indicator (section 6.2).

It should be noted that there have been controversial arguments regarding the issues in the measurement of income inequality. These arguments have their own merits and shortcomings, and there has been little professional consensus among researchers with regard to the theoretical superiority of a particular way of measuring inequality. We simply refer to a vast literature on the sensitivity of measured results to the choice of income definitions, inequality indices, appropriate equivalence scales, and other elements that may affect results in comparative research. ${ }^{9}$

\subsection{How to deal with pensions?}

An important choice in this kind of analysis is whether the total population should be covered or the working-age population only, an approach followed by Causa \& Hermansen (2017). A related choice is whether pensions should be earmarked as market income or as transfers and therefore pension contributions as taxes. This choice is of vital importance for the results. Most studies conclude that the redistributive effect of transfers is much more important than the redistributive effect of taxes; see section 2. But Guillaud et al (2017) show that if pensions are categorized as market income rather than transfers, tax redistribution dominates transfer redistribution in most countries. Restricting the analysis to the non-elderly would avoid some

9 Among others, see Atkinson (2003), Atkinson \& Brandolini (2001), Brandolini \& Smeeding (2007 and 2009) and Gottschalk \& Smeeding (1997). 
of the problems inherent to comparisons of incomes between people who are at different stages in their lives. For instance, an essential function of old-age pensions is to redistribute intertemporally over the life cycle; in that case a focus on the non-elderly helps in understanding the most important elements of interpersonal redistribution. However, we believe that in our analysis the largest government transfer program, public pensions, cannot be excluded. ${ }^{10}$ Public pension plans are generally seen as part of the safety net, generating large antipoverty effects. So, state old-age pension benefits will be included in our analysis on redistribution. But countries differ to a large extent in public versus private provision of their pensions (OECD, 2008: 120). Occupational and private pensions are not redistributive programs per se, although they too have a significant effect on redistribution when pre-taxtransfer inequality and post-tax-transfer inequality are measured at one moment in time, particularly among the elderly. The standard approach treats contributions to government pensions as a tax that finances the retirement pensions paid out in the same year, while contributions to private pensions are effectively treated as a form of private consumption. This may affect international comparisons of redistribution effects of social transfers and taxes. We deal with this bias rather pragmatically by following the LIS Household Income Variables List: occupational and private pensions are earmarked and treated as social security transfers. Jesuit \& Mahler (2017) also consider the pension system as whole, because the distinction between public and private pensions is somewhat artificial. For a substantial number of LIS countries it is impossible to disaggregate income from public and private schemes.

Because the arguments for focusing on the working population are also valid, we will present an analysis for both the working-age population and the total population.

\section{Inequality and fiscal redistribution across LIS countries around 2013}

\subsection{Inequality across countries}

This section reviews the evidence on cross national comparisons of annual disposable income inequality over 31 nations around 2013. Figure 1 shows the Gini coefficients. Countries are listed in order of their Gini of disposable income from smallest to largest. The obvious advantage of the presentation of inequality by summary statistics like the Gini coefficient is its ability to summarize several nations in one picture. Figure 1 indicates that a wide range of inequality exists across 31 LIS nations, with the nation with the highest inequality coefficient (South Africa) twice as high as the nations with the lowest coefficient (Nordic Countries).

10 For this reason Tony Atkinson has advised to take the total population into account in this analysis (LIS Summer Workshop 2012). 


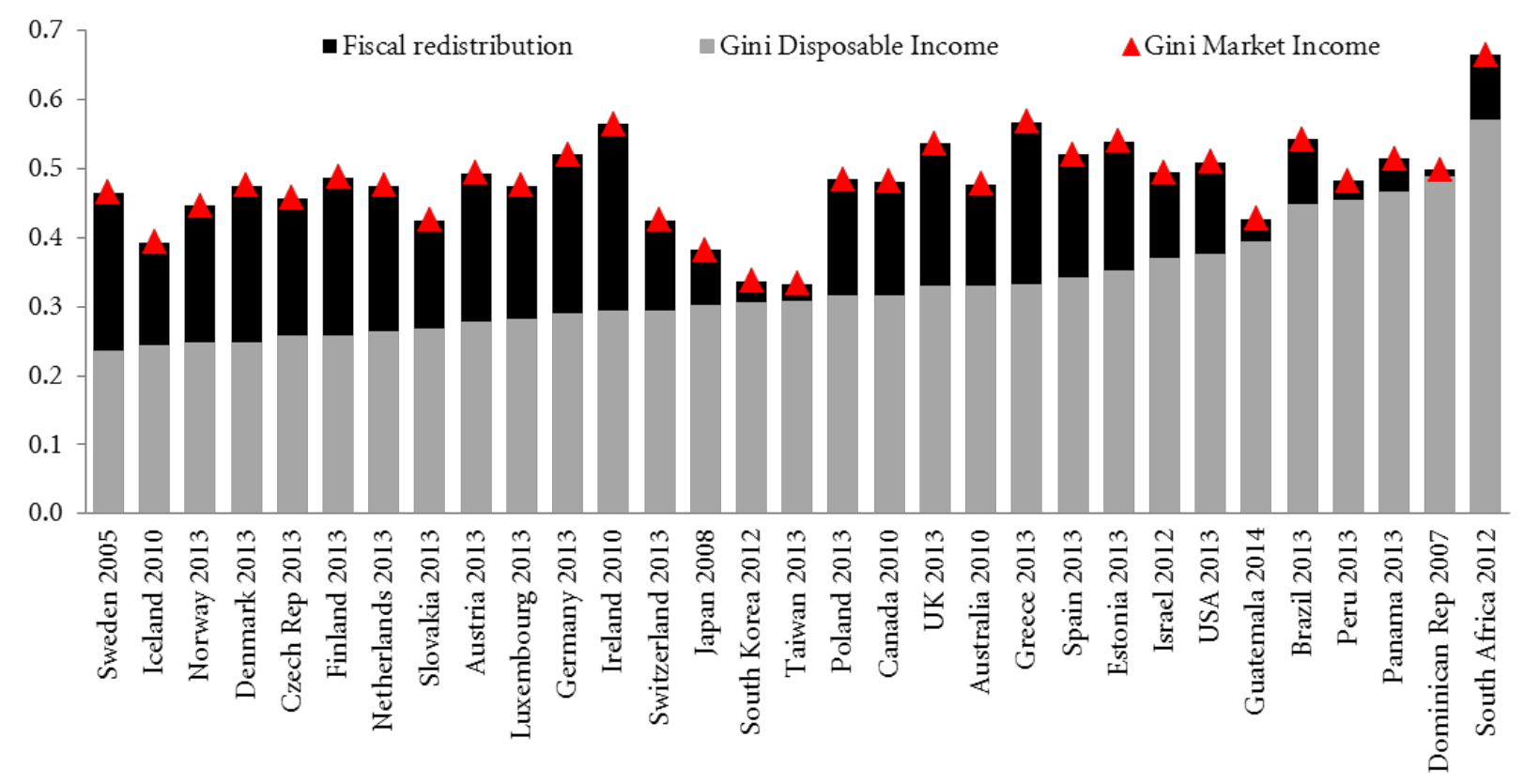

Source: Database Wang \& Caminada (2017) based on LIS, and own calculations

With respect to income inequality after social transfers and taxes, there are 22 countries with the Gini coefficient below average (0.33). Sweden, Iceland, Norway, Denmark, Czech Republic, Finland, the Netherlands and Slovakia have rather low values below 0.275, followed by other 13 countries (Austria, Luxembourg, Germany, Ireland, Switzerland, Japan, South Korea, Taiwan, Poland, Canada, the United Kingdom, Australia and Greece) with Gini coefficients between 0.275 and 0.350. Above average inequality is found in 10 countries (Spain, Estonia, Israel, the United States, Guatemala, Brazil, Peru, Panama, Dominican Republic and South Africa).

The pattern of market income inequality (before social transfers and taxes) is quite different from disposable income inequality. South Africa, Greece and Ireland have the highest level of market income inequality, with values above 0.55. Iceland, Japan, South Korea and Taiwan have rather low levels of market income inequality, below 0.40 . The redistributive effects of taxes and social transfers differ considerably across countries. The highest level of redistribution is found in Ireland, Greece, Germany, Nordic Countries, Austria, the Netherlands, and the United Kingdom, while fiscal redistribution is rather small in Panama, Guatemala, South Korea, Peru, Taiwan, and Dominican Republic.

\subsection{The redistributive effect of taxes and transfers}

Figure 2 shows the overall redistribution across countries and the disaggregated effects of social transfers and taxes. Countries are listed in order of their total redistribution from largest to smallest. On average, the share of social transfers plays a major role of 76 percent in the total reduction of inequality, while taxes (income taxes and mandatory payroll taxes) account for 24 percent of total reduction of income inequality. 


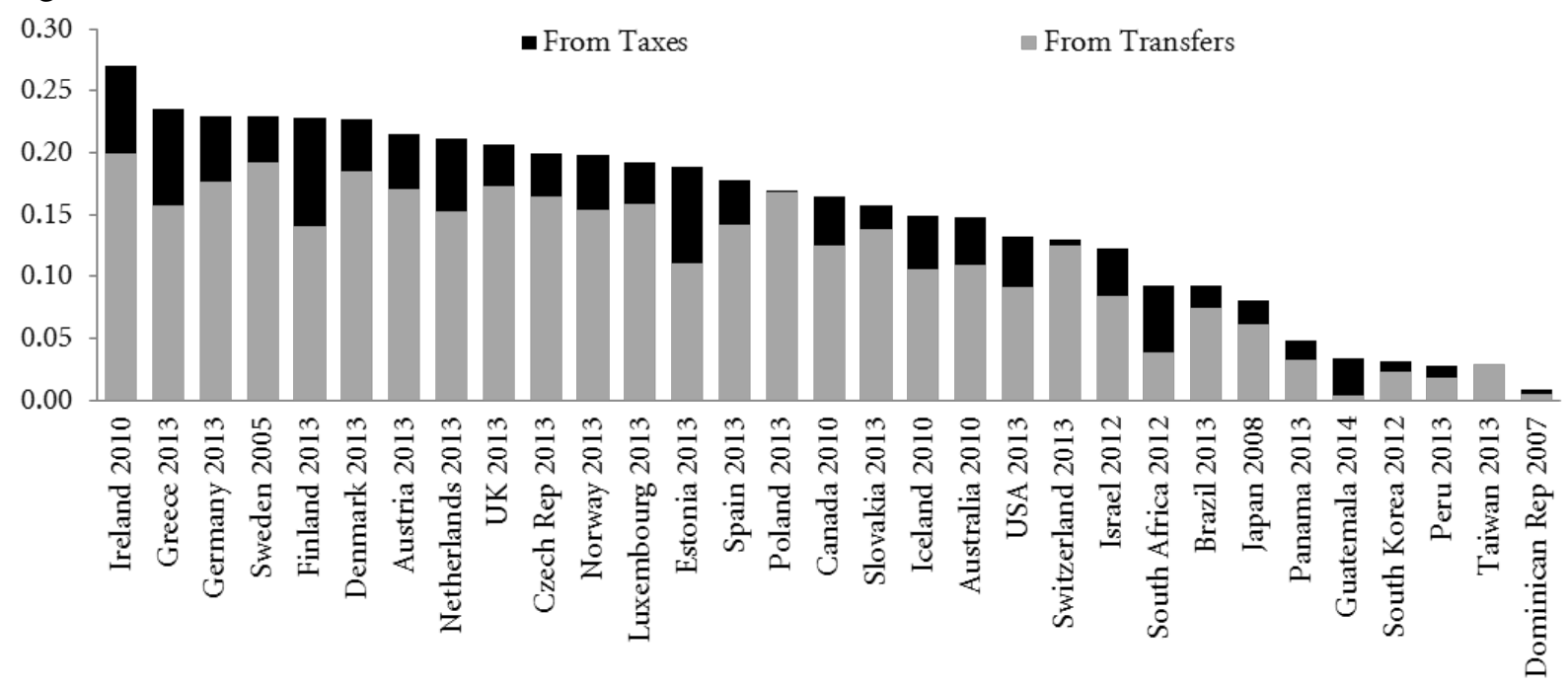

Source: Database Wang \& Caminada (2017) based on LIS, and own calculations

Only in a few countries taxes are important in equalizing incomes: Guatemala, South Africa, Dominican Republic and Estonia. Generally speaking, redistribution of income in most countries relies to a large extent on social transfers. This relative effect of social transfers and taxes in total redistribution is presented in Figure 3 (countries are listed according to the reduction of income inequality by taxes).

Figure 3 Relative redistributive effect of taxes and transfers across countries around 2013

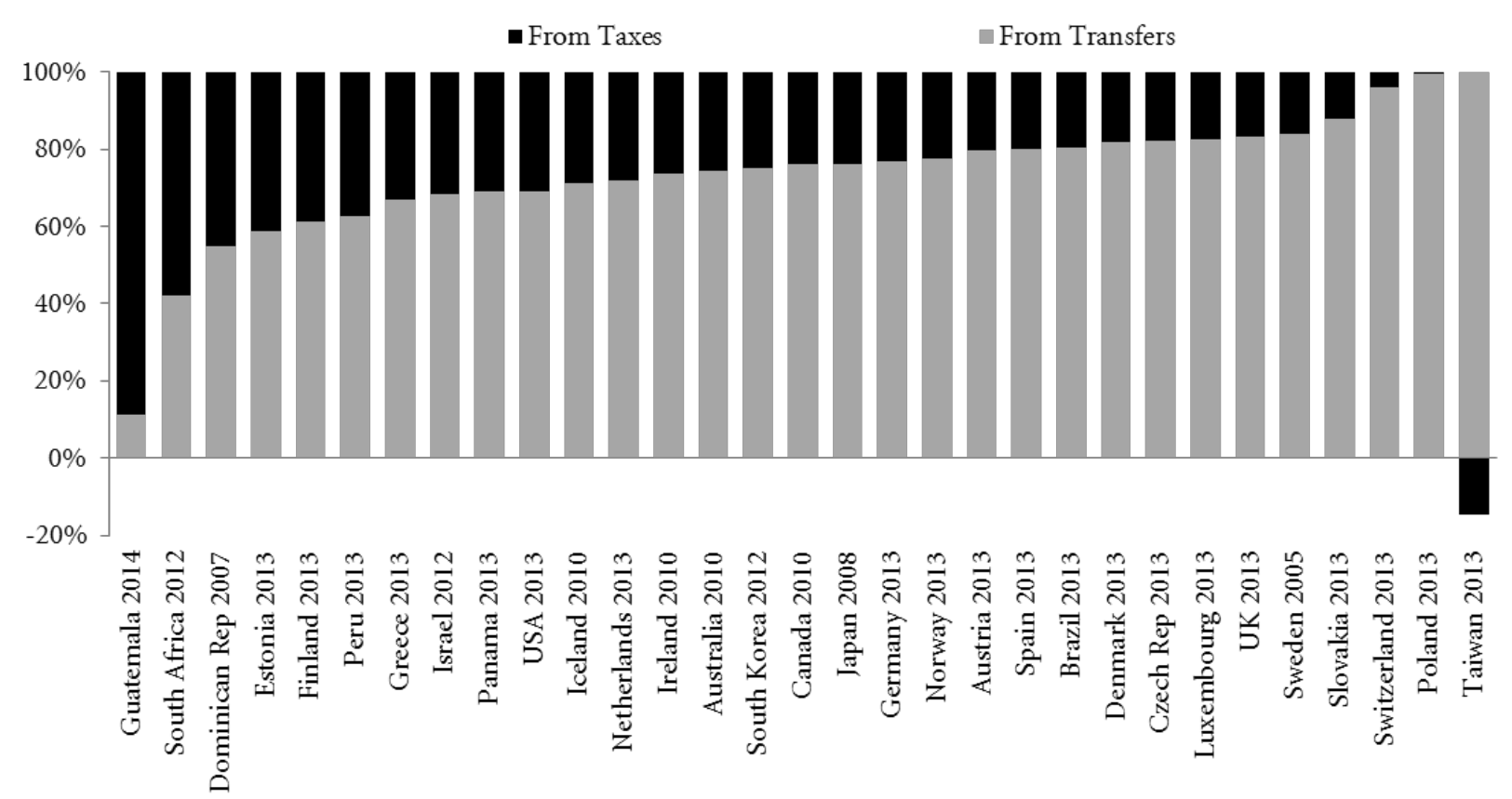

Source: Database Wang \& Caminada (2017) based on LIS, and own calculations 
Note that the partial effect of taxes is negative for Taiwan and rather low for Switzerland and Poland. The rather low contribution of taxes in total fiscal redistribution for Switzerland is caused by tax competition that leads to income segregation into low tax cantons, which in turn leaves the overall income tax system less progressive or even regressive (Schmidheiny, 2006). In this country it appears to be difficult to levy redistributive taxes from the rich and mobile persons. As a result the amount of taxes paid by rich people is relatively low.

As discussed in section 3.4, the results of the analysis will depend on whether the focus is on the total population or the non-elderly people (those aged 18-64) only. To show this, Table 2 summarizes the results for income inequality and fiscal redistribution among both the working-age population and the total population for 31 countries with full tax and benefit information. Both market income inequality and fiscal redistribution among the total population are - in all countries - higher compared to the working-age population (with the exception of Guatemala). In 19 out of 31 countries inequality of disposable income of the total population is higher compared to the working-age population. In both cases, the largest part of total fiscal redistribution comes from social transfers (as measured by the means of 31 countries); 76 percent for the total population versus 66 percent for the working-age population, while the remainder of total fiscal redistribution can be attributed to direct taxes. Additional calculations show that the correlation between inequality of the total population versus the working-age population is rather high. The same holds for fiscal redistribution. Pearson Correlation is .86 and over, indicating that the choice of the coverage of the population does matter, but not to a large extent. We conclude that focusing on the total population - from this point forward - will not give strong biases. 
Table 2 Redistributive effect of social transfers and taxes around 2013

\begin{tabular}{|c|c|c|c|c|c|c|c|c|c|c|c|c|}
\hline \multirow{3}{*}{ LIS Dataset } & \multicolumn{7}{|c|}{ Total population } & \multicolumn{5}{|c|}{ Working-age population } \\
\hline & \multicolumn{2}{|c|}{ Gini Coefficient } & \multicolumn{3}{|c|}{ Relative Fiscal Redistribution } & \multirow{2}{*}{$\begin{array}{c}\text { Budget size } \\
\text { transfers }\end{array}$} & \multirow{2}{*}{$\begin{array}{l}\text { Efficiency / } \\
\text { targeting }\end{array}$} & \multicolumn{2}{|c|}{ Gini Coefficient } & \multicolumn{3}{|c|}{ Relative Fiscal Redistribution } \\
\hline & $\begin{array}{l}\text { Market } \\
\text { Income }\end{array}$ & $\begin{array}{c}\text { Disposable } \\
\text { Income }\end{array}$ & Total & $\begin{array}{c}\text { Share from } \\
\text { Transfers }\end{array}$ & $\begin{array}{c}\text { Share from } \\
\text { Taxes }\end{array}$ & & & $\begin{array}{l}\text { Market } \\
\text { Income }\end{array}$ & $\begin{array}{c}\text { Disposable } \\
\text { Income }\end{array}$ & Total & $\begin{array}{c}\text { Share from } \\
\text { Transfers }\end{array}$ & $\begin{array}{c}\text { Share from } \\
\text { taxes }\end{array}$ \\
\hline Australia 2010 & 0.477 & 0.330 & $31 \%$ & $74 \%$ & $26 \%$ & 0.129 & -0.318 & 0.414 & 0.313 & $25 \%$ & $67 \%$ & $33 \%$ \\
\hline Austria 2013 & 0.493 & 0.279 & $44 \%$ & $80 \%$ & $20 \%$ & 0.261 & 0.045 & 0.417 & 0.280 & $33 \%$ & $70 \%$ & $30 \%$ \\
\hline Brazil 2013 & 0.542 & 0.450 & $17 \%$ & $80 \%$ & $20 \%$ & 0.204 & 0.158 & 0.516 & 0.444 & $14 \%$ & $74 \%$ & $26 \%$ \\
\hline Canada 2010 & 0.481 & 0.317 & $34 \%$ & $76 \%$ & $24 \%$ & 0.182 & -0.066 & 0.432 & 0.322 & $26 \%$ & $67 \%$ & $33 \%$ \\
\hline Czech Rep 2013 & 0.457 & 0.258 & $44 \%$ & $82 \%$ & $18 \%$ & 0.205 & -0.198 & 0.375 & 0.255 & $32 \%$ & $75 \%$ & $25 \%$ \\
\hline Denmark 2013 & 0.476 & 0.249 & $48 \%$ & $82 \%$ & $18 \%$ & 0.236 & -0.199 & 0.402 & 0.250 & $38 \%$ & $74 \%$ & $26 \%$ \\
\hline Dominican Rep 2007 & 0.498 & 0.490 & $2 \%$ & $55 \%$ & $45 \%$ & 0.028 & 0.026 & 0.490 & 0.483 & $1 \%$ & $51 \%$ & $49 \%$ \\
\hline Estonia 2013 & 0.540 & 0.352 & $35 \%$ & $59 \%$ & $41 \%$ & 0.191 & 0.022 & 0.473 & 0.349 & $26 \%$ & $44 \%$ & $56 \%$ \\
\hline Finland 2013 & 0.487 & 0.259 & $47 \%$ & $61 \%$ & $39 \%$ & 0.255 & -0.033 & 0.408 & 0.260 & $36 \%$ & $30 \%$ & $70 \%$ \\
\hline Germany 2013 & 0.520 & 0.291 & $44 \%$ & $77 \%$ & $23 \%$ & 0.224 & -0.118 & 0.419 & 0.296 & $29 \%$ & $62 \%$ & $38 \%$ \\
\hline Greece 2013 & 0.567 & 0.332 & $41 \%$ & $67 \%$ & $33 \%$ & 0.296 & 0.172 & 0.504 & 0.341 & $32 \%$ & $54 \%$ & $46 \%$ \\
\hline Guatemala 2014 & 0.427 & 0.394 & $8 \%$ & $11 \%$ & $89 \%$ & 0.028 & -0.039 & 0.430 & 0.398 & $7 \%$ & $3 \%$ & $97 \%$ \\
\hline Iceland 2010 & 0.393 & 0.245 & $38 \%$ & $71 \%$ & $29 \%$ & 0.164 & -0.125 & 0.347 & 0.245 & $29 \%$ & $62 \%$ & $38 \%$ \\
\hline Ireland 2010 & 0.564 & 0.294 & $48 \%$ & $74 \%$ & $26 \%$ & 0.268 & -0.087 & 0.517 & 0.294 & $43 \%$ & $69 \%$ & $31 \%$ \\
\hline Israel 2012 & 0.494 & 0.371 & $25 \%$ & $68 \%$ & $32 \%$ & 0.148 & 0.010 & 0.458 & 0.359 & $22 \%$ & $59 \%$ & $41 \%$ \\
\hline Japan 2008 & 0.382 & 0.302 & $21 \%$ & $76 \%$ & $24 \%$ & 0.149 & -0.036 & 0.351 & 0.303 & $14 \%$ & $59 \%$ & $41 \%$ \\
\hline Luxembourg 2013 & 0.475 & 0.283 & $40 \%$ & $82 \%$ & $18 \%$ & 0.260 & 0.106 & 0.416 & 0.283 & $32 \%$ & $75 \%$ & $25 \%$ \\
\hline Netherlands 2013 & 0.475 & 0.264 & $45 \%$ & $72 \%$ & $28 \%$ & 0.222 & -0.117 & 0.407 & 0.272 & $33 \%$ & $58 \%$ & $42 \%$ \\
\hline Norway 2013 & 0.446 & 0.248 & $44 \%$ & $78 \%$ & $22 \%$ & 0.232 & -0.064 & 0.391 & 0.258 & $34 \%$ & $70 \%$ & $30 \%$ \\
\hline Panama 2013 & 0.514 & 0.467 & $9 \%$ & $69 \%$ & $31 \%$ & 0.116 & 0.111 & 0.488 & 0.455 & $7 \%$ & $56 \%$ & $44 \%$ \\
\hline Peru 2013 & 0.483 & 0.455 & $6 \%$ & $63 \%$ & $37 \%$ & 0.073 & 0.131 & 0.460 & 0.438 & $5 \%$ & $52 \%$ & $48 \%$ \\
\hline Poland 2013 & 0.484 & 0.316 & $35 \%$ & $100 \%$ & $0 \%$ & 0.255 & 0.068 & 0.442 & 0.319 & $28 \%$ & $99 \%$ & $1 \%$ \\
\hline Slovakia 2013 & 0.425 & 0.268 & $37 \%$ & $88 \%$ & $12 \%$ & 0.209 & -0.108 & 0.361 & 0.269 & $26 \%$ & $85 \%$ & $15 \%$ \\
\hline South Africa 2012 & 0.664 & 0.572 & $14 \%$ & $42 \%$ & $58 \%$ & 0.106 & 0.193 & 0.636 & 0.571 & $10 \%$ & $23 \%$ & $77 \%$ \\
\hline South Korea 2012 & 0.337 & 0.306 & $9 \%$ & $75 \%$ & $25 \%$ & 0.046 & 0.050 & 0.304 & 0.283 & $7 \%$ & $68 \%$ & $32 \%$ \\
\hline Spain 2013 & 0.52 & 0.343 & $34 \%$ & $80 \%$ & $20 \%$ & 0.263 & 0.153 & 0.471 & 0.349 & $26 \%$ & $72 \%$ & $28 \%$ \\
\hline Sweden 2005 & 0.466 & 0.237 & $49 \%$ & $84 \%$ & $16 \%$ & 0.281 & -0.074 & 0.391 & 0.235 & $40 \%$ & $76 \%$ & $24 \%$ \\
\hline Switzerland 2013 & 0.425 & 0.295 & $31 \%$ & $96 \%$ & $4 \%$ & 0.172 & -0.144 & 0.346 & 0.285 & $18 \%$ & $94 \%$ & $6 \%$ \\
\hline Taiwan 2013 & 0.333 & 0.308 & $8 \%$ & $115 \%$ & $-15 \%$ & 0.099 & 0.077 & 0.308 & 0.296 & $4 \%$ & $152 \%$ & $-52 \%$ \\
\hline UK 2013 & 0.537 & 0.33 & $39 \%$ & $83 \%$ & $17 \%$ & 0.217 & -0.123 & 0.459 & 0.335 & $27 \%$ & $77 \%$ & $23 \%$ \\
\hline USA 2013 & 0.509 & 0.377 & $26 \%$ & $69 \%$ & $31 \%$ & 0.138 & -0.091 & 0.464 & 0.374 & $19 \%$ & $58 \%$ & $42 \%$ \\
\hline Mean LIS-31 & 0.481 & 0.332 & $31 \%$ & $76 \%$ & $24 \%$ & 0.182 & -0.020 & 0.429 & 0.330 & $23 \%$ & $66 \%$ & $34 \%$ \\
\hline
\end{tabular}

Source: Database Wang \& Caminada (2017) based on LIS, and own calculations 


\subsection{Redistribution, budget size and targeting}

Considering the redistributive effect of social benefits, scholars have distinguished between programs' size and the extent to which they are targeted toward low-income groups by meanstesting. In a seminal paper by Korpi \& Palme (1998: p. 663), they have posited a "paradox of redistribution" whereby "the more we target benefits to the poor . . . the less likely we are to reduce poverty and inequality." The paradox arises from the fact that highly targeted programs have the support of a small and isolated political base. As they put it, targeted programs offer "no rational base for a coalition between those above and below the poverty line. In effect, the poverty line splits the working class and tends to generate coalitions between better-off workers and the middle class against the lower sections of the working class" (Korpi \& Palme, 1998: p. 663). Comprehensive programs, on the other hand, even when they are organized according to social insurance principles, tend to encourage coalitions between the working and middle classes that leave low-income groups less isolated.

With this background in mind, it is useful to explore empirically these two aspects of transfers. Is redistribution associated with transfers' overall size or with their target efficiency? Is there, as is often suggested, a tradeoff between the two? Using LIS micro data it is possible to calculate a measure of the average value of social transfers as a percentage of households' pretax income (gross income): the larger the value, the greater the share of total income that derives from transfers. It is also possible to calculate a summary index of the degree to which transfers are targeted toward low-income groups. This is done by applying Kakwani's (1986) 'index of concentration' to transfers. This index takes on the value of -1.0 if the poorest person gets all transfer income, 0 if everybody gets an equal amount, and +1.0 if the richest person gets all transfer income (cf. Korpi \& Palme, 1998: p. 684). Figures for the size and target efficiency of social benefits are reported in Table 2 and Figure 4; more details can be found in Caminada et al (2017) and Wang \& Caminada (2017). As is shown, there is indeed considerable variance among developed countries in the average size of social benefits relative to total household income, ranging from $2.8 \%$ to $29.6 \%$. Some countries (Greece, Ireland, Spain and Austria) achieve the highest budget size of transfers (above 26\%), followed by twenty countries with values between $20 \%$ and $29 \%$, while seven countries have the lowest levels (less than 10\%). The budget size of the Unites States is far below-average (13.8\% versus $19.5 \%)$.

As for target efficiency, it is more diverse across countries. Greece has a rather high budget size of transfers (29.6\%), with transfer programs being slightly regressive in terms of the Kakwani index. Spain, Luxembourg and Poland have low target efficiency, but high social expenditures (above 25\%). Australia and Switzerland show high figures for transfer targeting although with a modest budget size (less than 18\%). The United States is one of the countries with both rather low social transfers and a quite low target efficiency. Interestingly, Australia, at the bottom of our list of budget size (12.9\%), achieves the highest target efficiency among rich countries. 
Figure 4 Redistribution, budget size and targeting across 31 LIS countries around 2013
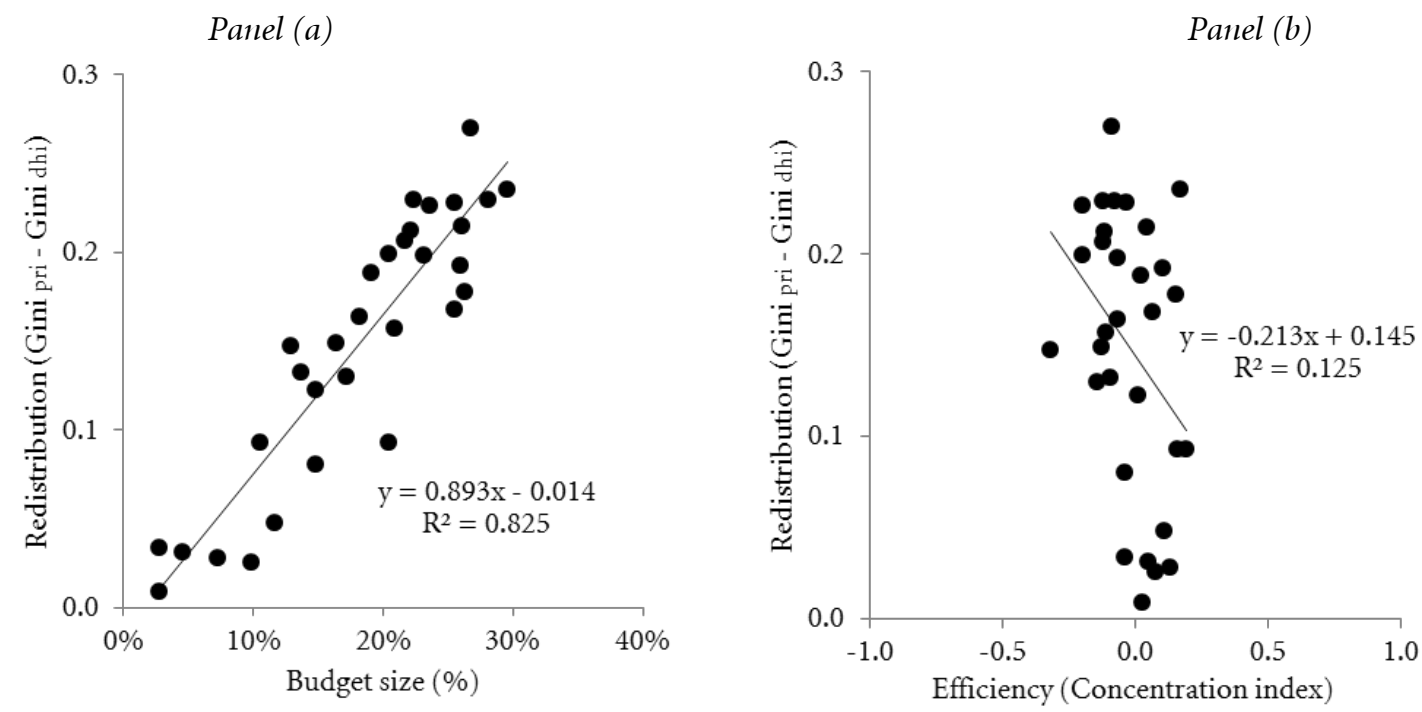

Source: Database Wang \& Caminada (2017) based on LIS, and own calculations

The budget size of transfers plays a very important role in overall redistribution, which is confirmed by a simple regression analysis in Figure 4 Panel (a). The estimated coefficient of the budget size is positive and statistically significant. Target efficiency is negatively associated with redistribution, although the linkage is weak (see Panel (b)). This is in line with the claim of Korpi \& Palme (1998: p. 663) that greater use of transfer targeting yields less redistribution. However, it should be noted that our analysis is based on 31 LIS countries. When we restrict our analysis to the seventeen wealthiest countries of LIS, the correlation with target efficiency disappears (see Figure 5). Redistribution of incomes across countries does not correlate with the target efficiency. This is in line with recent work of Kenworthy (2011:2-4).

Figure 5 Redistribution, budget size and targeting across rich countries around 2013
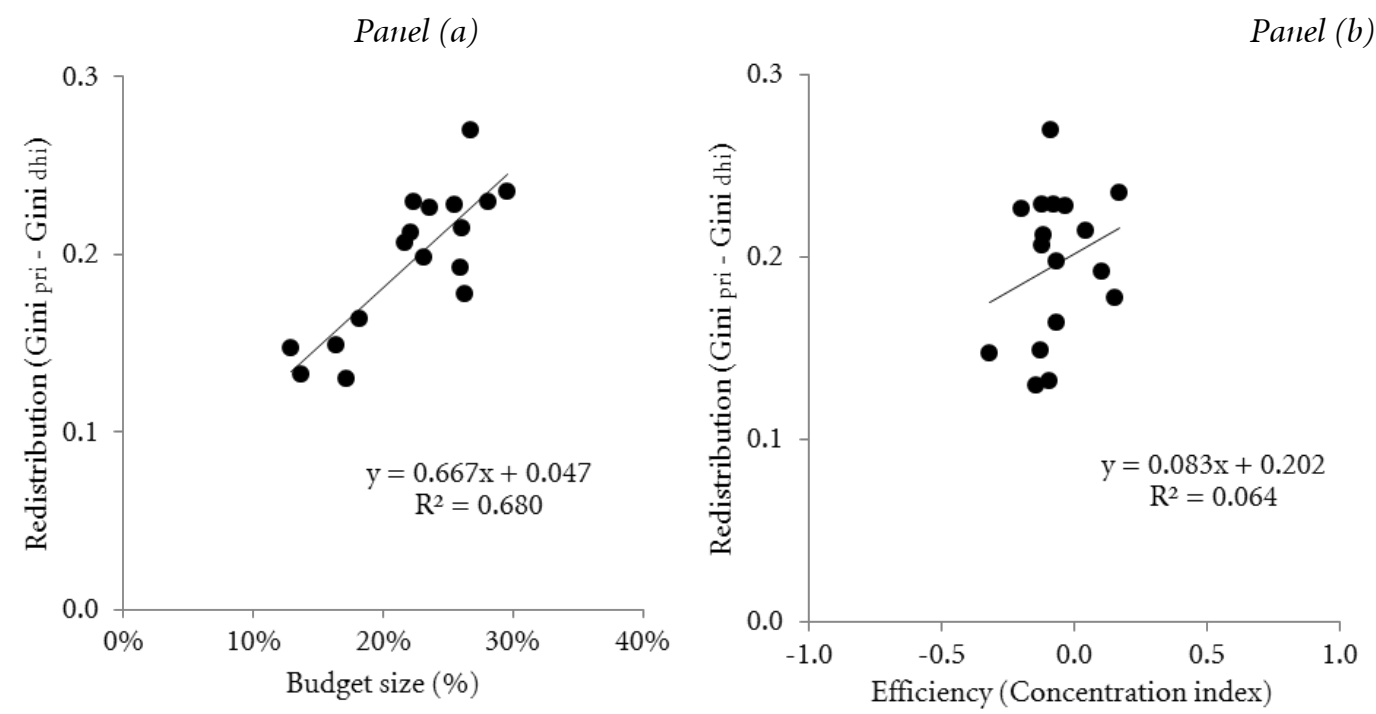

Selected LIS-countries: Australia, Austria, Canada, Denmark, Finland, Germany, Greece, Iceland, Ireland, Luxembourg, the Netherlands, Norway, Spain, Sweden, Switzerland, the United Kingdom, and the United States.

Source: Database Wang \& Caminada (2017) based on LIS, and own calculations 


\section{Decomposition of redistributive effects of social transfers and taxes across LIS countries around 2013}

\subsection{Budget size per social program}

This section provides detailed results of the redistributive effect of welfare state programs across a selection of our 31 countries based on the most recent wave of LIS. We elaborate on the work of Mahler \& Jesuit (2006) and Wang et al (2012 and 2014). However, we refine the Fiscal Redistribution approach. LIS data allow us to decompose the trajectory of the Gini coefficient from market to disposable income inequality in several parts: we will distinguish 9 different social benefits and income taxes and social contributions in our empirical investigation across countries. We calculate the following (partial) redistributive effects based on the LIS household income components list (see Documentation Guide Leiden LIS Budget Incidence Fiscal Redistribution Dataset on Income inequality, Wang \& Caminada, 2017): oldage/disability/survivor transfers, sickness transfers, family/children transfers, education transfers, unemployment transfers, housing transfers, general/food/medical assistance transfers, other social security transfers, and income taxes and social security contributions.

We explore empirically programs' size and the progressiveness of each social benefit; see section 4.3. Table 3 presents social benefits as a proportion of households' gross income for each benefit categorized in LIS. We selected 25 LIS countries for which full information is available on the whole trajectory from market income to disposable income for data year around 2013. ${ }^{11}$ Countries are listed in order of their level of budget size from largest to smallest.

We observe a considerable variance among developed countries in the average size of social benefits relative to total household income, ranging from 2.8\% (Guatemala) to 29.6\%

(Greece). Some countries (Greece, Ireland, Spain, Austria, and Luxembourg) achieve the highest budget size of transfers (above 26\%), followed by the majority of the countries with values between $20 \%$ and $26 \%$, while 7 countries have the lowest level (less than $15 \%$ ), among these the Unites States (13.8\%).

In most countries old-age/disability/survivor transfers account for 50 to 80 percent of total budget size. Family/children benefits account on average for 11 percent, unemployment compensation benefits for 5 percent and general/food/medical assistance benefits for 4 percent. Rather small social programs are sickness benefits, education transfers and housing benefits, accounting each for on average less than 1 percent of the total budget size. Transfers not allocated to a specific category (the category Other transfers) are somewhat troublesome in our decomposition analysis. In most countries the category Other transfers is rather small (share below 5\%), while in Australia, Guatemala and Israel it is above 10\%.

11 This analysis excludes countries with little or no information on specific social benefits, i.e. when the redistributive effect of the category Other transfers amounts over 25 percent of total fiscal redistribution. This is the case for Canada, Dominican Republic, Japan, South Korea, Sweden and Taiwan. 
Table 3 Social transfers as a proportion of households' gross income around 2013

\begin{tabular}{|c|c|c|c|c|c|c|c|c|c|}
\hline & $\begin{array}{c}\text { All } \\
\text { social } \\
\text { benefits }\end{array}$ & $\begin{array}{l}\text { Old-age/ } \\
\text { Disability/ } \\
\text { Survivors }\end{array}$ & Sickness & $\begin{array}{l}\text { Family/ } \\
\text { Children }\end{array}$ & Education & $\begin{array}{l}\text { Unemploy- } \\
\text { ment }\end{array}$ & Housing & $\begin{array}{l}\text { General/ } \\
\text { food/ } \\
\text { medical } \\
\text { assistance }\end{array}$ & Other \\
\hline Greece 2013 & 29.6 & 26.8 & 0.0 & 0.9 & 0.0 & 0.9 & 0.0 & & 0.5 \\
\hline Ireland 2010 & 26.8 & 11.5 & 1.4 & 5.7 & 0.1 & 6.1 & 0.8 & 0.3 & 0.8 \\
\hline Spain 2013 & 26.3 & 19.2 & 0.4 & 0.2 & 0.2 & 5.8 & 0.0 & & 0.5 \\
\hline Austria 2013 & 26.1 & 19.8 & 0.4 & 3.5 & 0.2 & 1.7 & 0.1 & 0.3 & 0.0 \\
\hline Luxembourg 2013 & 26.0 & 19.3 & 0.2 & 4.4 & 0.1 & 0.9 & 0.1 & 0.6 & 0.3 \\
\hline Poland 2013 & 25.5 & 22.5 & & 1.2 & 0.1 & 0.4 & 0.1 & 0.8 & 0.3 \\
\hline Finland 2013 & 25.5 & 16.8 & 0.1 & 2.2 & 0.5 & 3.1 & 0.6 & 0.4 & 1.7 \\
\hline Denmark 2013 & 23.6 & 15.5 & & 1.5 & 1.3 & 1.6 & 0.8 & 1.9 & 0.9 \\
\hline Norway 2013 & 23.2 & 16.3 & 2.3 & 2.6 & 0.4 & 0.6 & 0.1 & 0.3 & 0.6 \\
\hline Germany 2013 & 22.4 & 16.8 & & 3.1 & 0.3 & 1.9 & 0.1 & 0.1 & 0.1 \\
\hline Netherlands 2013 & 22.2 & 16.4 & 0.4 & 1.3 & 0.5 & 1.7 & 0.5 & 1.0 & 0.5 \\
\hline UK 2013 & 21.7 & 13.8 & 0.0 & 3.4 & 0.0 & 0.4 & 2.0 & 0.9 & 1.1 \\
\hline Slovakia 2013 & 20.9 & 16.6 & 0.2 & 2.8 & 0.1 & 0.3 & & & 0.8 \\
\hline Czech Rep 2013 & 20.5 & 16.4 & & 1.7 & & 0.4 & 0.4 & 0.4 & 1.3 \\
\hline Brazil 2013 & 20.4 & 18.0 & & & & 0.7 & & 1.4 & 0.4 \\
\hline Estonia 2013 & 19.1 & 13.5 & 0.7 & 3.9 & 0.1 & 0.5 & & 0.1 & 0.0 \\
\hline Switzerland 2013 & 17.2 & 12.9 & 0.0 & 2.0 & & 0.9 & 0.0 & & 1.3 \\
\hline Iceland 2010 & 16.4 & 10.6 & 0.0 & 2.2 & 0.2 & 1.8 & 1.5 & 0.1 & 0.0 \\
\hline Israel 2012 & 14.8 & 10.3 & & 1.8 & & 0.5 & & 0.5 & 1.8 \\
\hline USA 2013 & 13.8 & 11.0 & 0.1 & 1.3 & 0.7 & 0.4 & 0.1 & 0.7 & 0.1 \\
\hline Australia 2010 & 12.9 & 7.0 & 0.0 & 3.4 & 0.1 & 1.0 & 0.2 & 0.0 & 1.3 \\
\hline Panama 2013 & 11.6 & 9.4 & & 0.3 & 1.5 & & 0.0 & 0.4 & 0.0 \\
\hline South Africa 2012 & 10.6 & 6.0 & & 4.0 & & & & & 0.2 \\
\hline Peru 2013 & 7.3 & 4.0 & & 0.4 & 0.2 & & 0.0 & 2.6 & 0.0 \\
\hline Guatemala 2014 & 2.8 & 1.9 & & & 0.0 & & & 0.5 & 0.3 \\
\hline
\end{tabular}

Source: Database Wang \& Caminada (2017) based on LIS, and own calculations

\subsection{Fiscal redistribution per social program}

To illustrate the idea of decomposing disposable income inequality, Table 4 presents the results of our sequential accounting decomposition exercise for the mean of a selection of 25 LIS countries with full tax/benefit information. Among these countries relative fiscal redistribution is on average 33 percent.

Interestingly, only three programs account for 67 percent of total redistribution: oldage/disability/survivor scheme (53\%), social programs for family and children (8\%) and the unemployment scheme (6\%). Income taxes account for another 24 percent of total redistribution. Other social benefit programs and contributions seem to have a rather limited redistributive effect; together they account for only 9 percent of the reduction in income inequality through transfers. 
Table 4 Decomposition of disposable income inequality for 25 LIS countries around 2013

\begin{tabular}{lcc} 
& Gini \\
\hline (a) Gini market income & 0.496 & \\
(b) Gini disposable income & 0.333 & \\
Overall redistribution (a-b) & 0.163 & share \\
& & $77 \%$ \\
Transfers & 0.125 & $53 \%$ \\
Old-age/Disability/Survivor transfers & 0.087 & $1 \%$ \\
Sickness transfers & 0.002 & $8 \%$ \\
Family/Children transfers & 0.012 & $1 \%$ \\
Education transfers & 0.002 & $6 \%$ \\
Unemployment transfers & 0.010 & $2 \%$ \\
Housing transfers & 0.004 & $3 \%$ \\
General/food/medical assistance transfers & 0.005 & $2 \%$ \\
Other transfers & 0.003 & \\
& & $24 \%$ \\
Income taxes and social security contributions & 0.039 & \\
& & $-1 \%$ \\
Residual & -0.001 & $100 \%$ \\
\hline
\end{tabular}

Notes:

- When we take the mean of the decomposition results across countries, the sum of all partial redistributive effects amount (a little) over 100 percent due to missing observations. We rescale the redistributive effects of each social program by applying an adjustment factor, which is defined as the overall redistribution given by formula (4) $(=100 \%)$ divided by sum of all partial redistributive effects of all programs (over $100 \%$ ), in order to correct for an over-estimated effect.

- LIS 25: Australia, Austria, Brazil, Czech Republic, Denmark, Estonia, Finland, Germany, Greece, Guatemala, Iceland, Ireland, Israel, Luxembourg, the Netherlands, Norway, Panama, Peru, Poland, Slovakia, South Africa, Spain, Switzerland, the United Kingdom and the United States.

Source: Database Wang \& Caminada (2017) based on LIS, and own calculations

In Table 5 we present the results of the decomposition of the trajectory of the Gini coefficient from market to disposable income inequality for groups of countries for the latest data year available in LIS. We clustered all countries in groups, among which English speaking countries, Continental European countries, Nordic countries, according to Esping-Anderson types of welfare states (Esping-Andersen \& Myles, 2009). 
Table 5 Decomposition of income inequality and redistributive effect of social transfers and taxes (latest data year)

\begin{tabular}{|c|c|c|c|c|c|c|c|c|c|c|c|c|c|c|}
\hline & & & & & \multicolumn{10}{|c|}{ Partial effects (shares) } \\
\hline LIS Dataset & 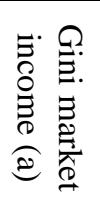 & 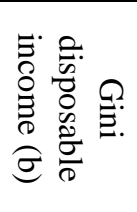 & 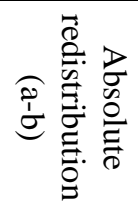 & 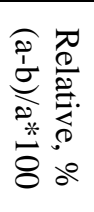 & 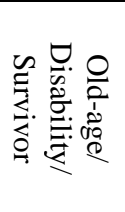 & 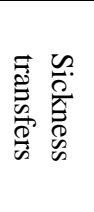 & 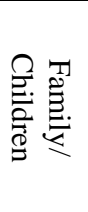 & 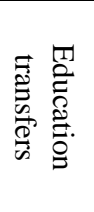 & $\begin{array}{l}\subseteq \\
\subseteq \\
0 \\
0 \\
0 \\
0 \\
0 \\
0 \\
0\end{array}$ & 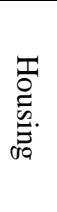 & 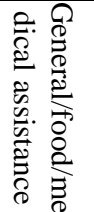 & 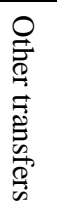 & 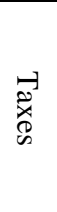 & 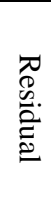 \\
\hline
\end{tabular}

\section{panel a: LIS English speaking countries}

\begin{tabular}{l|ll} 
Australia 2010 & 0.477 & 0.330 \\
Ireland 2010 & 0.564 & 0.294 \\
United Kingdom 2013 & 0.537 & 0.330 \\
United States 2013 & 0.509 & 0.377
\end{tabular}

panel b: LIS Continental European countries

\begin{tabular}{|c|c|c|c|c|c|c|c|c|c|c|c|c|c|c|}
\hline Austria 2013 & 0.493 & 0.279 & 0.215 & $44 \%$ & $62 \%$ & $1 \%$ & $8 \%$ & $1 \%$ & $6 \%$ & $1 \%$ & $2 \%$ & $0 \%$ & $20 \%$ & $0 \%$ \\
\hline Germany 2013 & 0.520 & 0.291 & 0.229 & $44 \%$ & $61 \%$ & & $6 \%$ & $1 \%$ & $9 \%$ & $1 \%$ & $0 \%$ & $0 \%$ & $23 \%$ & $0 \%$ \\
\hline Luxembourg 2013 & 0.475 & 0.283 & 0.192 & $40 \%$ & $60 \%$ & $0 \%$ & $12 \%$ & $0 \%$ & $4 \%$ & $1 \%$ & $4 \%$ & $1 \%$ & $18 \%$ & $0 \%$ \\
\hline Switzerland 2013 & 0.425 & 0.295 & 0.130 & $31 \%$ & $77 \%$ & $0 \%$ & $6 \%$ & & $4 \%$ & $0 \%$ & & $9 \%$ & $4 \%$ & $0 \%$ \\
\hline \multicolumn{15}{|c|}{ panel c: LIS Nordic countries } \\
\hline Denmark 2013 & 0.476 & 0.249 & 0.226 & $48 \%$ & $58 \%$ & & $2 \%$ & $5 \%$ & $4 \%$ & $4 \%$ & $8 \%$ & $2 \%$ & $18 \%$ & $-1 \%$ \\
\hline Finland 2013 & 0.487 & 0.259 & 0.228 & $47 \%$ & $54 \%$ & $0 \%$ & $4 \%$ & $2 \%$ & $9 \%$ & $3 \%$ & $2 \%$ & $-4 \%$ & $39 \%$ & $-9 \%$ \\
\hline Iceland 2010 & 0.393 & 0.245 & 0.149 & $38 \%$ & $48 \%$ & $0 \%$ & $8 \%$ & $0 \%$ & $9 \%$ & $5 \%$ & $1 \%$ & $0 \%$ & $29 \%$ & $0 \%$ \\
\hline Netherlands 2013 & 0.475 & 0.264 & 0.212 & $45 \%$ & $56 \%$ & $1 \%$ & $3 \%$ & $2 \%$ & $4 \%$ & $3 \%$ & $6 \%$ & $0 \%$ & $28 \%$ & $-2 \%$ \\
\hline Norway 2013 & 0.446 & 0.248 & 0.198 & $44 \%$ & $60 \%$ & $4 \%$ & $6 \%$ & $1 \%$ & $2 \%$ & $1 \%$ & $2 \%$ & $2 \%$ & $22 \%$ & $0 \%$ \\
\hline \multicolumn{15}{|c|}{ panel d: LIS Southern European countries } \\
\hline Greece 2013 & 0.567 & 0.332 & 0.235 & $41 \%$ & $61 \%$ & $0 \%$ & $2 \%$ & $0 \%$ & $2 \%$ & $0 \%$ & & $1 \%$ & $33 \%$ & $0 \%$ \\
\hline Spain 2013 & 0.520 & 0.343 & 0.177 & $34 \%$ & $59 \%$ & $1 \%$ & $1 \%$ & $1 \%$ & $17 \%$ & $0 \%$ & & $2 \%$ & $20 \%$ & $0 \%$ \\
\hline \multicolumn{15}{|c|}{ panel e: LIS Central Eastern European countries } \\
\hline Czech Republic 2013 & 0.457 & 0.258 & 0.199 & $44 \%$ & $69 \%$ & & $5 \%$ & & $1 \%$ & $2 \%$ & $2 \%$ & $3 \%$ & $18 \%$ & $0 \%$ \\
\hline Estonia 2013 & 0.540 & 0.352 & 0.188 & $35 \%$ & $53 \%$ & $0 \%$ & $4 \%$ & $0 \%$ & $1 \%$ & & $0 \%$ & $0 \%$ & $41 \%$ & $0 \%$ \\
\hline Poland 2013 & 0.484 & 0.316 & 0.168 & $35 \%$ & $86 \%$ & & $6 \%$ & $0 \%$ & $2 \%$ & $1 \%$ & $4 \%$ & $1 \%$ & $0 \%$ & $0 \%$ \\
\hline Slovakia 2013 & 0.425 & 0.268 & 0.157 & $37 \%$ & $73 \%$ & $0 \%$ & $9 \%$ & $0 \%$ & $1 \%$ & & & $5 \%$ & $12 \%$ & $0 \%$ \\
\hline
\end{tabular}


Table 5 Decomposition of income inequality ..... (continued)

\begin{tabular}{|c|c|c|c|c|c|c|c|c|c|c|c|c|c|c|}
\hline & & & & & \multicolumn{10}{|c|}{ Partial effects (shares) } \\
\hline LIS Dataset & 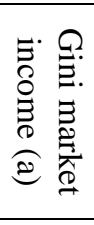 & 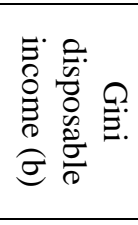 & 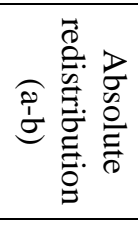 & 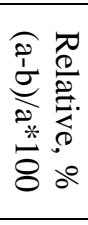 & 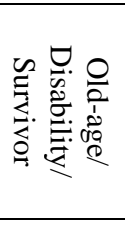 & 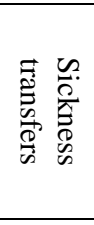 & 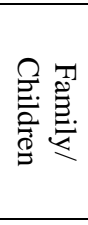 & 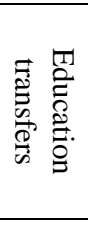 & 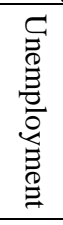 & 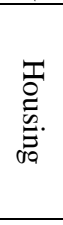 & 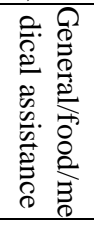 & 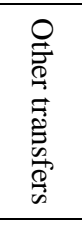 & 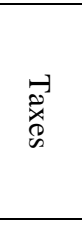 & 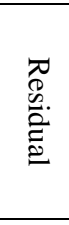 \\
\hline \multicolumn{15}{|c|}{ panel f: LIS BRICS } \\
\hline Brazil 2013 & 0.542 & 0.450 & 0.093 & $17 \%$ & $61 \%$ & & & & $4 \%$ & & $15 \%$ & $2 \%$ & $20 \%$ & $-1 \%$ \\
\hline South Africa 2012 & 0.664 & 0.572 & 0.093 & $14 \%$ & $24 \%$ & & $17 \%$ & & & & & $-1 \%$ & $58 \%$ & $1 \%$ \\
\hline \multicolumn{15}{|c|}{ panel g: Latin America } \\
\hline Guatemala 2014 & 0.427 & 0.394 & 0.034 & $8 \%$ & $-3 \%$ & & & $1 \%$ & & & $8 \%$ & $6 \%$ & $88 \%$ & $0 \%$ \\
\hline Panama 2013 & 0.514 & 0.467 & 0.048 & $9 \%$ & $33 \%$ & & $8 \%$ & $21 \%$ & & $0 \%$ & $8 \%$ & $0 \%$ & $31 \%$ & $0 \%$ \\
\hline Peru 2013 & 0.483 & 0.455 & 0.028 & $6 \%$ & $21 \%$ & & $16 \%$ & $3 \%$ & & $0 \%$ & $23 \%$ & $0 \%$ & $37 \%$ & $0 \%$ \\
\hline \multicolumn{15}{|l|}{ panel g: LIS others } \\
\hline Israel 2012 & 0.494 & 0.371 & 0.123 & $25 \%$ & $45 \%$ & & $9 \%$ & & $2 \%$ & & $4 \%$ & $9 \%$ & $32 \%$ & $0 \%$ \\
\hline Mean-LIS 25 & 0.496 & 0.333 & 0.163 & $33 \%$ & $53 \%$ & $1 \%$ & $8 \%$ & $1 \%$ & $6 \%$ & $2 \%$ & $3 \%$ & $2 \%$ & $24 \%$ & $-1 \%$ \\
\hline
\end{tabular}

Notes: See below Table 4

Source: Database Wang \& Caminada (2017) based on LIS, and own calculations. 
In most countries two dominant income components account for above 80 percent of total reduction in income inequality: the old-age/disability/survivor scheme, and the income taxes. However, cross country differences are huge. For example, in Switzerland, Poland and Slovakia, old-age/disability/survivor schemes account for over 70 percent of income redistribution while in Ireland and Peru it contributes less than 30 percent. We even observe a negative impact in Guatemala.

Large redistributive effects through income taxes and contributions can be found in most country groups (with the exception of the Continental European countries). The United Kingdom, Luxembourg, Switzerland, Denmark, Czech Republic, Poland, and Slovakia are special cases because the income taxes contribute for a relatively small part (below 20\%) to the reduction of income inequality between market and disposable income.

The redistributive effect of family/children benefits is relatively high in the English speaking Countries (8-19\%), compared to Nordic Countries (2-8\%), Continental European Countries (6-8\% with the exception of Luxembourg), and Central Eastern European Countries (4-9\%). Unemployment compensation benefits do have some effect too, especially in Continental European countries and Nordic countries. Remarkably, across countries all other social benefit programs appear to have rather limited redistributive effects.

It should be noted that the results are hardly affected by the ordering effect. The partial redistributive effect of a specific social transfer will be highest (smallest) when computed as the first (last) social program; see section 3.1. Our analysis shows that the residual term is rather modest and in most cases below 2 percent (with an exception for Finland).

\section{Sensitivity analyses}

\subsection{Different equivalence scales methods}

Our figures on income inequality and fiscal redistribution may be influenced by the equivalence scales method applied. To test this sensitivity we apply three widely used equivalence scales methods: from LIS (this study), OECD modified, and OECD original. Table 6 presents the results. Levels of income inequality and fiscal redistribution as measured by different equivalence scales methods hardly show differences. The measured fiscal redistribution ranges from 0.149 to 0.153 (means of 31 countries). Moreover, all equivalence scales methods show that by far the largest part of total fiscal redistribution comes from social transfers (share ranges from 76 to 77 percent), while taxes play a minor role (ranging from 23 to 24 percent). Pearson Correlation of levels of income inequality and fiscal redistribution across all 31 countries for the three equivalence scales methods show values of .99 and over (not shown), indicating that the equivalence scale method used hardly matters. 
Table 6 Impact of three different equivalence scales methods: Mean Gini of 31 countries

\begin{tabular}{l|cc|c|cc|}
\cline { 2 - 6 } & $\begin{array}{c}\text { Gini } \\
\text { Total Population } \\
\text { Market Income }\end{array}$ & $\begin{array}{c}\text { Gini } \\
\text { Total Population } \\
\text { Disposable Income }\end{array}$ & $\begin{array}{c}\text { Fiscal } \\
\text { Redistribution }\end{array}$ & $\begin{array}{c}\text { Share from } \\
\text { Transfers }\end{array}$ & $\begin{array}{c}\text { Share from } \\
\text { Taxes }\end{array}$ \\
\hline LIS equivalence scale & 0.481 & 0.332 & 0.149 & $76 \%$ & $24 \%$ \\
OECD modified & 0.483 & 0.330 & 0.152 & $76 \%$ & $24 \%$ \\
OECD original & 0.489 & 0.336 & 0.153 & $77 \%$ & $23 \%$ \\
\hline Range (Max - Min) & 0.008 & 0.005 & 0.004 & $1 \%$ & $1 \%$ \\
\hline
\end{tabular}

Source: Database Wang \& Caminada (2017) based on LIS, and own calculations.

\subsection{Different global income inequality indices}

It is well-known from the literature that levels of measured income inequality and fiscal redistribution depend on the global inequality indicator used. To test this sensitivity we apply five widely used indicators: Gini, Atkinson Coefficient (with e $=0.5$ and e $=1.0$ ), Mean Log Deviation and Theil Coefficient. Of course, levels of income inequality and fiscal redistribution as measured by these indicators differ; see Table 7 . The highest level of fiscal redistribution is measured by Mean Log Deviation and Atkinson Coefficient $(e=1)$, while other indices produce rather comparable levels of fiscal redistribution. Moreover, all indicators show that by far the largest part of total fiscal redistribution comes from social transfers (share ranges from 76 to 92 percent), while taxes play a minor role (ranging from 8 to 24 percent).

Note, however, that Pearson Correlation of levels of income inequality across all 31 countries show values of .98 and over for disposable income, illustrating that our results do not seem to be very sensitive to the global income inequality indicator used. Pearson correlation of fiscal redistribution is .93 and over, while figures for market income inequality are somewhat lower ( 0.83 and over). Figure 6 illustrates fiscal redistribution as measured by five global indicator for 31 countries. Countries are ranked by the level of fiscal redistribution by the Gini's. Note that other global indicators of inequality show a rather similar pattern (although levels of redistribution vary), i.e. the country ranking hardly alters, with an exception for Mean Log Deviation. We conclude that the levels of income inequality and the magnitude of fiscal redistribution indeed depend on the indicator used, but that both the country ranking of fiscal redistribution and the decomposition of fiscal redistribution (shares of transfers versus taxes) do not seem to depend that much on the global indicator of income inequality used. 
Table 7 Impact several global income inequality indicators: Mean indicators of 31 countries

\begin{tabular}{l|cc|c|cc|}
\cline { 2 - 6 } & $\begin{array}{c}\text { Inequality } \\
\text { Total population } \\
\text { Market Income }\end{array}$ & $\begin{array}{c}\text { Inequality } \\
\text { Total population } \\
\text { Disposable Income }\end{array}$ & $\begin{array}{c}\text { Fiscal } \\
\text { Redistribution }\end{array}$ & $\begin{array}{c}\text { Share from } \\
\text { Transfers }\end{array}$ & $\begin{array}{c}\text { Share from } \\
\text { Taxes }\end{array}$ \\
\hline Gini Coefficient & 0.481 & 0.332 & 0.149 & $76 \%$ & $24 \%$ \\
Atkinson Coefficient (eps=0.5) & 0.231 & 0.098 & 0.133 & $85 \%$ & $15 \%$ \\
Atkinson Coefficient (eps=1) & 0.513 & 0.190 & 0.323 & $90 \%$ & $10 \%$ \\
Mean Log Deviation & 0.751 & 0.217 & 0.534 & $92 \%$ & $8 \%$ \\
Theil Coefficient & 0.426 & 0.207 & 0.219 & $79 \%$ & $21 \%$ \\
\hline Range (Max - Min) & 0.520 & 0.234 & 0.401 & $16 \%$ & $16 \%$ \\
\hline
\end{tabular}

Source: Database Wang \& Caminada (2017) based on LIS, and own calculations.

Figure 6 Fiscal redistribution as measured by several inequality indicators (Total population)

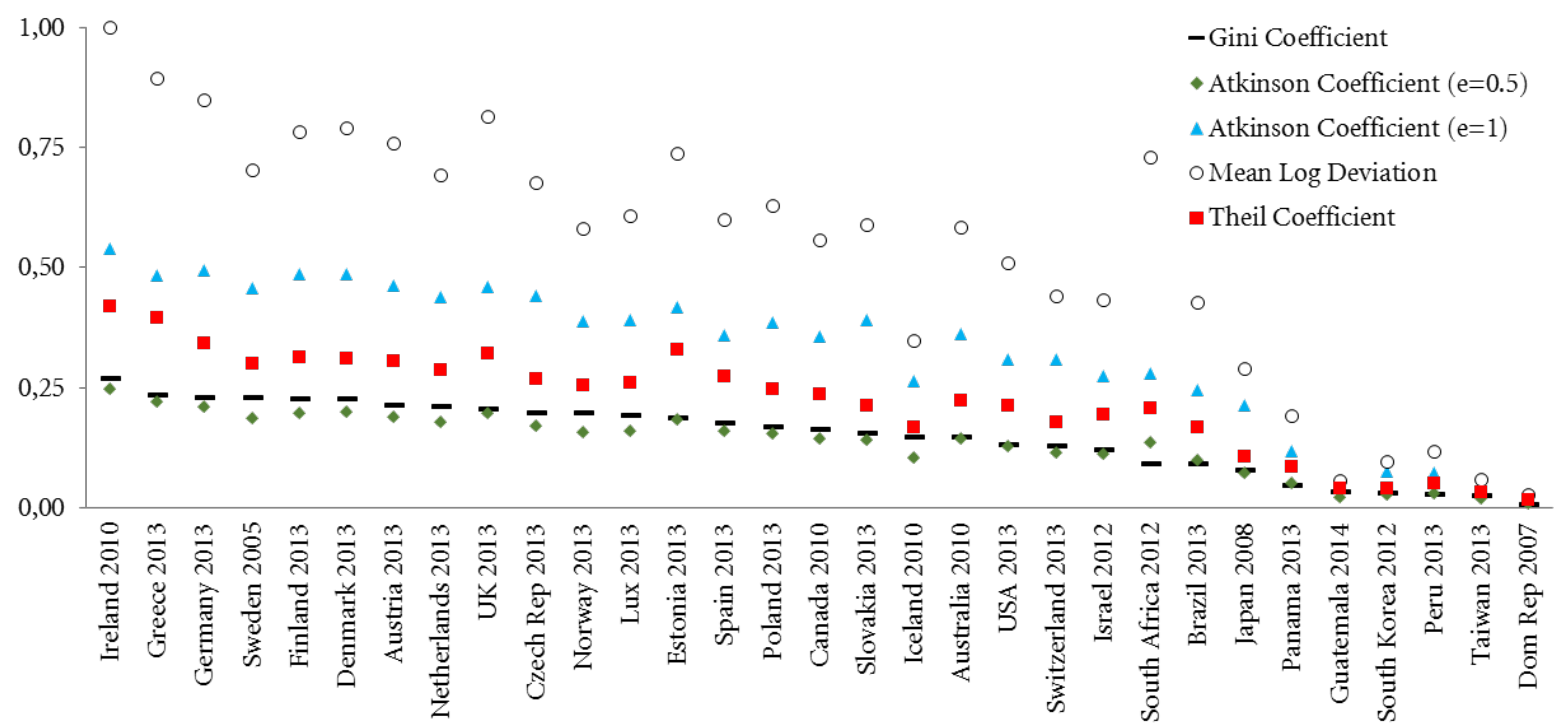

Source: Database Wang \& Caminada (2017) based on LIS, and own calculations.

\section{Conclusion}

In this paper we have investigated the redistributive effect attributed to social transfers and taxes across 31 countries in the aftermath of the Great Recession, based on the micro household income data from LIS. We have provided market and disposable income inequality, total and disaggregated redistributions in a comparative way, across more countries than that have been studied before, offering an accurate, detailed picture of redistribution of incomes through taxes and transfers across countries.

Nordic countries, Czech Republic and the Netherlands have the smallest income disparity, while Brazil, Peru, Panama, Dominican Republic, and South Africa have the largest. Nordic countries show the most equally distributed disposable incomes and market incomes. On average, large market income disparity exists in English speaking countries. Generally speaking, European countries achieve lower levels of income inequality than other countries. 
With respect to redistributive effects, our budget incidence analysis indicates that the pattern is diverse across countries. The largest redistribution is found for Ireland, Greece, Germany, Nordic Countries, Austria and the Netherlands, while South Korea, Peru, Taiwan, and Dominican Republic show rather limited overall redistributive effects. On average for the 31 countries, the share of social transfers in total redistribution is 76 percent, while income taxes account for 24 percent of redistribution. Thus, in most countries social transfers are the dominant instruments in reducing income inequality. We also find that this redistributive effect can almost fully be attributed to the budget size of transfers, while the extent to which benefits are targeted toward low income groups does not seem to play a significant role.

As far as specific social programs are concerned, in most countries two dominant income components account for 50 to 80 percent of total reduction in income inequality: the public old-age pensions and the survivors schemes (including disability benefits), and the income taxes. However, cross country differences are huge. For example, in Continental European, Central Eastern European and Southern European Countries the public old-age and survivor benefits account for a large part of total redistribution, while these figures are much lower for English speaking Countries (29-53\%), for Nordic Countries (48-60\%). In Nordic Countries, English speaking Countries and Latin America income taxes play a major role (above 25\%) compared to other countries (with the exceptions of the United Kingdom, Denmark and Norway). The redistributive effect of social assistance (family and children benefits) is in the English speaking Countries relatively high (8-19\%), compared to Nordic Countries (2-8\%), Continental European Countries (6-12\%), and Central Eastern European Countries (4-9\%). In Nordic Countries also a variety of other social programs contribute to the reduction of inequality. Remarkably, across countries all other social benefit programs seem to have rather limited redistributive effects, although the food and medical assistance schemes do have some effect too.

Altogether, we find for the 31 countries in this study that just after the crisis the mean of pregovernment Gini indices of income inequality was 0.496 . After adding government transfers and deducting income taxes and social insurance contributions the Gini fell to 0.333, representing a Gini reduction of 14.9 points or 31 percent. We have performed several sensitivity analyses. Focusing on the working-age population only reduces redistribution from 31 percent to 23 percent and also reduces the share of social transfers in redistribution, but not by much. Applying other equivalence scales methods hardly change the results. Using other global income inequality indicators affects the magnitude of fiscal redistribution, but does not have much influence on country rankings and on the decomposition of fiscal redistribution.

The result for total redistribution is roughly equivalent to what Wang et al (2014) found for the mid 2000's. Thus we can conclude that despite several budget cuts and reforms of social programs during the crisis, welfare states are still rather effective in reducing income inequality. 


\section{References}

Atkinson, AB. 2003: Income Inequality in OECD Countries: Data and Explanations. CESifo Economic Studies 49(4): 479-513.

Atkinson, AB. 2015: Inequality: What can be Done. Harvard University Press: Cambridge, Massachusetts.

Atkinson, AB and Brandolini, A. 2001: Promise and Pitfalls in the Use of Secondary Data-Sets: Income Inequality in OECD Countries as a Case Study. Journal of Economic Literature 39(3): 771-800.

Atkinson, AB, Brandolini, A and Smeeding, T. 2001: Producing Time Series Data for Income Distribution: Sources, Methods, and Techniques. LIS Working Paper Series 295.

Atkinson, AB, Rainwater, L and Smeeding, TM. 1995: Income Distribution in OECD Countries: Evidence from the Luxembourg Income Study. OECD Social Policy Studies 18.

Avram, S, Levy, H and Sutherland, H. 2014: Income Redistribution in the European Union. IZA Journal of European Labor Studies 3(22): 1-29.

Belfield, C, Blundell, R, Cribb, J, Hood, A and Joyce, R. 2017: Two Decades of Income Inequality in Britain: The Role of Wages, Household Earnings and Redistribution. Economica 84: 157-179.

Bradley, D, Huber, E, Moller, S, Nielsen, F and Stephens, J. 2003: Distribution and Redistribution in Postindustrial Democracies. World Politics 55(2): 193-228.

Brandolini, A and Smeeding, TM. 2007: Inequality: International Evidence. In: Durlauf, SN and Blume, LE (eds). The New Palgrave Dictionary of Economics, 1013-1021. Palgrave Macmillan: Basingstoke.

Brandolini, A and Smeeding, TM. 2009: Income Inequality in Richer and OECD Countries, in: Salverda, W, Nolan, B and Smeeding, TM (eds). The Oxford Handbook of Economic Inequality. Oxford University Press: Oxford.

Caminada, K and Goudswaard, KP. 2001: International Trends in Income Inequality and Social Policy. International Tax and Public Finance 8(4): 395-415.

Caminada, K, Wang, J, Goudswaard, KP and Wang, C. 2017: Income inequality and fiscal redistribution in 47 LIS-countries (1967-2014). LIS Working Paper Series nr. 724.

Causa, O and Hermansen M. 2017: Income redistribution through taxes and transfers across OECD countries. OECD Economics Department Working Paper, no 1453, OECD Publishing.

Chevan, A and Stokes, R. 2000: Growth in Family Income Inequality, 1970-1990: Industrial Restructuring and Demographic Change. Demography 37: 365-380.

Creedy, J and Ven, J. 2001: Decomposing Redistributive Effects of Taxes and Transfers in Australia: Annual and Lifetime Measures. Australian Economic Papers 40(2): 185-198.

Danziger, S, Haveman, R and Plotnick, R. 1981: How Income Transfer Programs Affect Work, Savings and Income Distribution: A Critical Assessment. Journal of Economic Literature 19: 975-1028.

De Agostini, P, Paulus, A, Sutherland, H and Tasseva, I. 2014: The Effect of Tax-Benefit Changes on the Income Distribution in EU Countries Since the Beginning of the Economic Crisis. EUROMOD Working Paper no. EM9/14.

Esping-Andersen, G and Myles, J. 2009: Economic Inequality and the Welfare State. In: Salverda, W, Nolan, B and Smeeding, TM (eds). The Oxford Handbook of Economic Inequality, 639-664. Oxford University Press: New York.

Ferrarini, T and Nelson, K. 2003: Taxation of Social Insurance and Redistribution: a Comparative Analysis of Ten Welfare States. Journal of European Social Policy 13(1): 21-33. 
Figini, P. 1998: Inequality Measures, Equivalence Scales and Adjustment for Household Size and Composition. LIS Working Paper Series 185.

Figari, F and Paulus, A. 2015: The Distributional Effects of Taxes and Transfers Under Alternative Income Concepts: The Importance of Three "I"s. Public Finance Review 43(3): 347-372.

Fuest C, Niehues, J and Peichl, A. 2010: The redistributive effects of tax benefit systems in the enlarged EU. Public Finance Review 38(4): 473-500.

Gornick, JC, Ragnarsdóttir, BH and Kostecki, S. 2013: LIS, Cross-National Data Center in Luxembourg - An Overview. LIS Technical Working Paper Series \#5.

Gottschalk, P and Smeeding, TM. 1997: Cross-National Comparisons of Earnings and Income Inequality. Journal of Economic Literature 35(2): 633-687.

Gottschalk, P and Smeeding, TM. 2000: Empirical Evidence on Income Inequality in Industrialized Countries. In: Atkinson, AB and Bourguignon, F (eds). Handbook of Income Distribution, 261-308. North-Holland: Amsterdam.

Guillaud, E, Olckers, M and Zemmour, M. 2017: Four Levers of Redistribution: The Impact of Tax and Transfer Systems on Inequality Reduction, LIS Working Papers Series \#695.

Gustafsson, B and Johansson, M. 1999: In Search of Smoking Guns: What Makes Income Inequality Vary over Time in Different Countries? American Sociological Review 64: 585-605.

Hills, J, Paulus, A, Sutherland, H and Tasseva, I. 2014: A Lost Decade? Decomposing the Effect of 2001-11 Tax-Benefit Policy Changes on the Income Distribution in EU Countries. ImPRovE Working Papers, 14/03. ImPRovE, Antwerp: Belgium.

Immervoll, H and Richardson, L. 2011: Redistribution Policy and Inequality Reduction in OECD Countries: What Has Changed in Two Decades? OECD Social, Employment and Migration Working Papers no. 122. OECD Publishing.

Jenkins, SP. 1995: Accounting for Inequality Trends: Decomposition Analyses for the UK 1971-86. Economica 62: 29-63.

Jesuit, DK. and Mahler, VA. 2010: Comparing Government Redistribution across Countries: The Problem of Second-order Effects. LIS Working Paper Series \#546.

Jesuit, D and Mahler, V. 2017: Fiscal Redistribution in Comparative Perspective: Recent Evidence from the Luxembourg Income Study (LIS) Data Centre. In: Buggeln, M, Daunton, M and Nützenadel, A (eds). The Political Economy of Public Finance: Taxation, State Spending and Debt since the 1970s, 177-198. Cambridge University Press: Cambrigde.

Joumard, I, Pisu, M and Bloch, D. 2012: Tackling Income Inequality: The Role of Taxes and Transfers, OECD Journal: Economic Studies (1): 37-70.

Kakwani, NC. 1986: Analyzing Redistribution Policies: A Study Using Australian Data. Cambridge University Press: Cambridge.

Kammer, A, Niehues, J and Peichl, A. 2012: Welfare regimes and welfare state outcomes in Europe. Journal of European Social Policy 22(5): 455-471.

Kenworthy, L and Pontusson, J. 2005: Rising Inequality and the Politics of Redistribution in Affluent Countries. Perspectives on Politics 3(3): 449-471.

Kenworthy, L. 2011: Targeting May Not Be So Bad. In: Progress for the Poor. Oxford University Press: New York.

Kim, H. 2000: Anti-Poverty Effectiveness of Taxes and Income Transfers in Welfare States. International Social Security Review 53(4): 105-129. 
Kim, H. 2001: Do Welfare States Reduce Poverty? A Critical Shortcoming in the Standard Analysis of the Anti-Poverty Effect of Welfare States. European Journal of Social Security 3 (1): 25-44.

Korpi, W and Palme, J. 1998: The Paradox of Redistribution and Strategies of Equality: Welfare State Institutions, Inequality, and Poverty in the Western Countries. American Sociological Review 63: 661-687.

Kristjánsson , AS. 2011: Income Redistribution in Iceland: Development and European Comparisons. European Journal of Social Security 13(4): 392-423.

Kuznets, S. 1955: Economic Growth and Income Inequality. American Economic Review 45: 1-28.

Lambert, PJ, Nesbakken, R and Thoresen, TO. 2010: On the Meaning and Measurement of Redistribution in Cross-Country Comparisons. LIS Working Paper Series \#532.

Lerman, RI and Yitzhaki, S. 1985: Income Inequality Effects by Income Source: A New Approach and Applications to the United States. The Review of Economics and Statistics 67(1): 151-156.

LIS Cross-National Data Center in Luxembourg. 2017: Luxembourg Income Study (LIS) Database, http://www.lisdatacenter.org, accessed between August and October 2017 (through the secured remote-execution system from the LIS database, for 47 countries).

Mahler, VA and Jesuit, DK. 2006: Fiscal redistribution in the developed countries: new insights from the Luxembourg Income Study. Socio-Economic Review 4: 483-511.

Musgrave, RA, Case, KE and Leonard, HB. 1974: The Distribution of Fiscal Burdens and Benefits, Public Finance Quarterly 2(July): 259-311.

Nielsen, F and Alderson, AS. 1997: The Kuznets Curve and the Great U-Turn: Patterns of Income Inequality in U.S. Counties, 1970-1990. American Sociological Review 62: 12-33.

Nieuwenhuis, R, Munzi, T and Gornick. JC 2016: Comparative research with net and gross income data: An evaluation of two netting down procedures for the LIS Database. Review of Income and Wealth. DOI: 10.1111/roiw.12233.

Nolan, B and Marx, I. 2009: Economic Inequality, Poverty, and Social Exclusion. In: Salverda, W, Nolan, B and Smeeding, TM (eds). The Oxford Handbook of Economic Inequality, 315-341. Oxford University Press: New York.

OECD. 2008: Growing unequal? Income distribution and Poverty in OECD Countries. OECD: Paris.

OECD. 2011: Divided We Stand: Why Inequality Keeps Rising. OECD: Paris.

OECD. 2015: In It Together: Why Less Inequality Benefits All. OECD: Paris.

OECD. 2016: Income Inequality remains high in the fact of weak recovery. OECD: Paris.

Piketty, T. 2014: Capital in the Twenty-First Century,. The Belknap Press of Harvard University Press: Cambridge.

Plotnick, R. 1984: The Redistributive Impact of Cash Transfers. Public Finance Quarterly 12: 27-50.

Pressman, S. 2009: Public Policies and the Middle Class throughout the World in the Mid 2000s. LIS Working Paper Series \#517.

Ravallion, M. 2015: The Luxembourg Income Study. The Journal of Economic Inequality 13: 527-547. (DOI 10.1007/s10888-015-9298-y).

Ringen, S. 1991: Households, standard of living and inequality. Review of Income and Wealth 37: 1-13.

Shorrocks , AF. 1982: Inequality decomposition by factor components. Econometrica 50: 193-211.

Shorrocks, AF. 1983: Ranking Income Distributions. Economica 50(197): 3-17. 
Smeeding, TM. 2000: Changing Income Inequality in OECD Countries: Updated Results from the Luxembourg Income Study (LIS). In: Hauser, R and Becker, I (eds). The Personal Distribution of Income in an International Perspective, 205-224. Springer-Verlag: Berlin, Germany.

Smeeding, TM. 2004: Twenty Years of Research in Income Inequality, Poverty and Redistribution in the Developed World: Introduction and Overview. Socio-Economic Review 2: 149-163.

Smeeding, T and Latner, JP. 2015: PovcalNet, WDI and 'All the Ginis': a critical review. The Journal of Economic Inequality 13 (4): 603-628.

Schmidheiny, K. 2006: Income segregation and local progressive taxation: Empirical evidence from Switzerland. Journal of Public Economics, 90(3): 429-458.

Smolensky, E, Hoyt, W and Danziger, S. 1987: A Critical Survey of Efforts to Measure Budget Incidence. In: HM van de Kar \& BL Wolfe (eds). The Relevance of Public Finance for PolicyMaking, 165-179. Proceedings IIFP Congress 1985, Detroit.

Stark, O, Taylor, JE and Yitzhaki, S. 1986: Remittances and inequality. Economic Journal 96: 722-740.

Wang C, Caminada, K and Goudswaard, KP. 2012: The redistributive effect of social transfer programmes and taxes: A decomposition across countries. International Social Security Review 65(3): 27-48.

Wang, C, Caminada, K and Goudswaard, KP. 2014: Income distribution in 20 countries over time. International Journal of Social Welfare 23(3): 262-275.

Wang, J and Caminada, K 2017: Leiden LIS Budget Incidence Fiscal Redistribution Dataset on Income inequality. https://www.universiteitleiden.nl/en/law/institute-for-tax-law-and-economics/economics/data-sets/leidenlis-budget-incidence-fiscal-redistribution-dataset-on-income-inequality-for-47-lis-countries---1967-2014

Whiteford, P. 2010: The Australian Tax-Transfer System: Architecture and Outcomes. The Economic Record 86(275): 528-544. 